\title{
NEW INSIGHTS INTO THE GENESIS OF PYRODUCTS OF THE GALÁPAGOS ISLANDS, ECUADOR
}

\author{
NOVA SPOZNANJA O NASTANKU PIRODUKTOV \\ GALAPAŠKEGA OTOČJA, EKVADOR
}

\author{
Stephan $\mathrm{KEMPE}^{1^{*}}$, Greg MIDDLETON ${ }^{2}$, Aaron ADDISON ${ }^{3}$, \\ Theofilos TOULKERIDIS ${ }^{4,5}$ \& Geoffrey HOESE ${ }^{6}$
}

\begin{abstract}
UDC 552.313.1:551.44(866.4)

Stephan Kempe, Greg Middleton, Aaron Addison, Theofilos Toulkeridis \& Geoffrey Hoese: New insights into the genesis of pyroducts of The Galápagos islands, Ecuador

There has been little research on the genesis and development of pyroducts (or lava tubes) originating from Galápagos volcanoes. Pyroducts are responsible for the lateral, post-eruptive transport of lava because they are highly effective as thermal insulators. After eruptions terminate, these conduits often become accessible as caves. In March 2014 the 16th International Symposium on Vulcanospeleology brought a large group of vulcanospeleological specialists to the Islands. During the meeting a number of pyroducts were visited and studied in context on the island of Santa Cruz and around Isabella's Sierra Negra volcano in the western, most active, part of the Galápagos. The longest of the caves, Cueva del Cascajo, about $3 \mathrm{~km}$ in length, was partly surveyed and nine other caves were visited. Structural features such as thickness of roof, evidence of downcutting, presence of oxbows, secondary ceilings, lavafalls, collapses and pukas were particularly studied for evidence they reveal about developmental stages of pyroducts. The resulting data show that the pyroducts were formed by "inflation" with the primary roof consisting of uninterrupted pāhoehoe sheets. No pyroducts were identified that developed by the crusting-over of channels. The studies strongly confirm inferences drawn from other hot-spot related islands, such as Hawai'i.

Key words: Ecuador, Galapagos Islands, volcanic rock caves, pyroducts, lava caves, speleogenesis.

Izvleček UDK 552.313.1:551.44(866.4)
Stephan Kempe, Greg Middleton, Aaron Addison, Theofilos
Toulkeridis \& Geoffrey Hoese: Nova spoznanja o nastanku
piroduktov Galapaškega otočja, Ekvador Raziskav o nastanku in razvoju piroduktov ali lavinih cevi na galapaških vulkanih je malo. Pirodukti so pomembni za bočni transport lave po izbruhu in so toplotni ščit med tokom lave in zunanjim ozračjem. Po končanem izbruhu ti kanali ostanejo dostopni kot lavine cevi. Marca 2014 je na Galapaškem otočju potekal 16. mednarodni simpozij o vulkanospeleologiji. V okviru tega smo obiskali in proučevali številne pirodukte na otoku Santa Cruz in v okolici vulkana Isabella's Sierra Negra na zahodnem, najaktivnejšem delu Galapaškega otočja. Delno smo izmerili najdaljšo, $3 \mathrm{~km}$ dolgo jamo Cueva del Cascajo in obiskali še devet drugih jam. Pri tem smo bili pozorni na strukturne elemente, ki kažejo na razvojne faze piroduktov, kot so debelina stropa, vrezovanje, prisotnost obvodnih rovov (oxbow), ostankov lavinih slapov, sekundarnih stropov, odprtin na površje (puka) in vdorov. Podatki in opažanja kažejo, da so jame nastale $\mathrm{z}$ zaporednim napredovanjem in napihovanjem, na kar kaže tudi primarni strop iz neprekinjenih plasti pahoehoe lave.. Nobeden od piroduktov ni nastal zaradi strjevanja lave nad tokom. Podobne ugotovitve veljajo tudi jame na vulkanih drugih vročih točk, kot na primer na havajskih vulkanih.

Ključne besede: Ekvador, Galapaško otočje, vulkanske jame, pirodukti, lavine jame, speleogeneza.

1 Technische Universität Darmstadt, Institute of Applied Geosciences, Schnittspahn Straße 9, D-64287 Darmstadt, Germany, email: kempe@geo.tu-darmstadt.de

2 Sydney Speleological Society PO Box 269, TAS-7006, Sandy Bay, Tasmania, Australia, email: ozspeleo@iinet.net.au

${ }^{3}$ Washington University in St. Louis, University Libraries, 1 Brookings Drive, Campus Box 1061, St. Louis, MO-63130, Missouri, USA, email: aaddison@wustl.edu

${ }^{4}$ Universidad de las Fuerzas Armadas ESPE, Campus Sangolquí, Av. Gral. Rumiñahui s/n, Sangolquí, P.O.BOX 171-5-231B, Ecuador, email: ttoulkeridis@espe.edu.ec

${ }^{5}$ Universidad de Especialidades Turísticas, Machala Oe6-160, Quito, Ecuador, email: ttoulkeridis@espe.edu.ec

${ }^{6}$ Texas Speleological Survey, 14045 North Green Hills Loop, TX-78737, Austin, Texas, USA, email: geoff.hoese@gmail.com

* Corresponding author
\end{abstract}




\section{INTRODUCTION}

Although a large number of researchers have studied the origin and development of volcanoes, their geological processes and landforms (e.g., Lockwood \& Hazlett 2010), speleology in the volcanic environment and the understanding of the formation of lava caves is still a debated topic (e.g., Sigurdsson et al. 2000; Heliker et al. 2003). For those researchers seeking to understand what happens during the formation of volcanic caves and the processes that are responsible for their formation and enlargement, much appears still to be learned (e.g., Kempe 2002, 2012, 2019; Bunnell 2013; Sauro et al. 2019). In order to further work on some of the most fundamental questions in this research area, the $16^{\text {th }} \mathrm{In}$ ternational Symposium on Vulcanospeleology (ISV) was held in Puerto Ayora on Santa Cruz Island, Galápagos. Excursions acquainted the international participants not only with the lava caves on this island, but also with the volcanoscape on the neighboring island of Isabella (where three caves were visited). The meeting was organized by Theofilos Toulkeridis (Ecuador) and Aaron Addison (USA) and attended by ca. 80 cavers, many of whom were exposed to the problems of vulcanospeleology for the first time. This high number of attendees in this remote region indicates that support for this specific speleological topic is increasing. Since then, further symposia were held in 2016 on Hawai $i$ and in 2018 at Lava Beds, California. The proceedings of these symposia are a prime source of the most recent research results in the field, accessible through the ISV site: http://www.vulcanospeleology.org/symposia.html. In 1991 Dr. W.R. Halliday organized the $6^{\text {th }}$ ISV on Hawaii (Rea 1992). Since then, the number of caves and the kilometers surveyed by members of the Hawaiian Speleological Survey (HSS) and other organizations has been multiplied by a factor probably close to 100 , illustrating the outstanding role of the Hawaiian volcanism in the understand of the underlying processes responsible for lava cave genesis. The Bulletin of the HSS ("Hawai'i Underground") informs about the most recent research results. However, we still are far from understanding cave development associated with flowing lava in all its facets.

Here we briefly discuss the insights into the genesis of the volcanic caves, or pyroducts, obtained during the Galápagos meeting with regard to the caves visited in Hawai' $i$ and elsewhere. These "insights" are mostly a number of in situ-observations leading to questions, many of which will need much more research in this expanding field of volcanology and associated landforms. The "insights" also owe much to the continuing discussion between the participants of the Galápagos symposium and with the authors during the fieldwork. It is not the intent of this paper to review the extensive international vulcanological and local speleological publications: for this the reader is for example referred to, for example Kempe $(2002,2019)$ or Sauro et al. (2020).

\section{GEOLOGICAL SETTING}

The presently active Galápagos hotspot has produced several voluminous shield-volcanoes, most of which are inactive due to the ESE-movement of the overlying Nazca oceanic plate (Holden \& Dietz 1972; Hey 1977). The main Galápagos Islands are located east of the N-Strending East Pacific Rise and south of the E-W-trending Galápagos Spreading Center and some 1,000 km west of the Ecuadorian mainland (Fig. 1). With an area of less than $45,000 \mathrm{~km}^{2}$ the Galápagos Islands represent one of the most volcanically active regions of the world (Simkin et al. 1981).

In the case of the Galápagos hot spot, this process of magma supply has existed for more than 90 million years $(\mathrm{Ma})$ while the lithospheric plate has moved many thousands of kilometers in the same time interval, carrying the hot spot-generated volcanoes away (Hoernle et al. 2002; Werner et al. 2003). Two aseismic volcanic ridges were created, the NE-moving Cocos Ridge and the E-moving Carnegie Ridge and associated seamounts on the Cocos and Nazca Plates, respectively (Harpp et al. 2003). These submarine extinct volcanic ridges are the result of cooling/contraction reactions of magma, as they slowly sank below the sea surface due to the lack of magma supply, lithospheric movement and strong erosional processes.

With time, these submarine volcanic ridges as well as various microplates, have accreted on the South American continent (Reynaud et al. 1999; Harpp \& White 2001). Western islands just above the Galápagos hot spot have the morphology of large shield volcanoes with deep calderas, while the eastern island volcanoes are small shield volcanoes with gentle slopes and almost without calderas (McBirney \& Williams 1969). Exceptions to the general picture of the main Galápagos Islands 
are the northern islands of Wolf and Darwin, which are considered to be a result of the interaction of the Galápagos hot spot and the Galápagos Spreading Center (Harpp \& Geist 2002). Holocene and historic eruptions have occurred on the main 16 active volcanoes of the Galápagos. Frequently associated with the shield volcanoes are hundreds of short-lived relatively small, cinder-, ash- and spatter cones. Some extinct volcanoes are represented by the islands Española, Santa Fe, Pinzon and Rabida. The island of Española is, at some $4 \mathrm{Ma}$, the oldest extinct volcano of the Galápagos while parts of the volcanic activities at San Cristobal island are almost 2.5 Ma old (Hall 1983; White et al. 1993). Many volcanic features such as lava caves, 'áā, pāhoehoe and pillow lava, olivine beaches and many more are encountered in almost all islands and reflect the interesting volcanic evolution of the Galápagos, which combined with its geodynamic relation, gave rise to the unique endemic life on these islands (Darwin 1859).

Santa Cruz is the most central island of the Galápagos. It is a large shield volcano with a high abundance of parasitic cones, large lava caves and enormous pit craters (e.g., Los Gemelos) and is subdivided into two main units (Bow 1979). The older unit is the Platform Unit with an age of 1.3-1.1 Ma, while the younger unit is represented by lavas of the Shield Series with ages as young as 30-20 ka (Bow 1979; White et al. 1993) (Fig. 1). The plagioclase and olivine phenocryst-bearing tholeiitic lavas of the platform series include faulted and uplifted parts which appear today as independent islands such as Baltra, Seymour and Las Plazas. The latter was evidently formed below the sea surface due to the almost exclusive occurrence of pillow basalt. These old and therefore lower units show intercalations with marine carbonates with a precipitation depth of $<100 \mathrm{~m}$. Based on their morphology and the lack of vegetation, the younger overlying lavas of the Shield series appear to be only a few thousand years old (White et al. 1993). These lavas, which mainly flowed from the summit but also from the flank of the volcano, are composed of a range of different volcanics, mainly exhibiting olivine tholeiites and transitional alkalibasalts besides some hawaiites (Bow 1979; White et al. 1993).

The Sierra Negra shield volcano on the western island, Isabela, is volcanically young and one of the most active volcanoes in the Galápagos. This volcano is 40 to 60 $\mathrm{km}$ wide and has, with its 9-10 km diameter caldera, the largest but simultaneously the shallowest elliptical caldera of all volcanoes of the Galápagos. Eruptive centers and different lava fields have been divided into five distinctive age groups, all being younger than 6000 years (Reynolds et al. 1995). These are alkaline to tholeiitic lava flows that erupted from E- to NE-trending circumferential and radial fissures situated on both sides of the summit caldera on the upper flanks and on the western and eastern lower flanks (Chadwick \& Howard 1991). The caldera itself has undergone several episodes of collapse, upheaval and deformation (Amelung et al. 2000; Vigouroux et al. 2008). These are alkaline to tholeiitic basaltic lava flows erupted from east to northeast, with circumferential and radial fissures situated on both sides of the summit caldera on the upper flanks and on the western and eastern lower flanks (Kurz \& Geist 1999). Ten historic eruptions occurred in the last 200 years. The last eruptive activity took place at the end of October 2005 and lasted a week, after 26 years of quiescence (Geist et al. 2008).

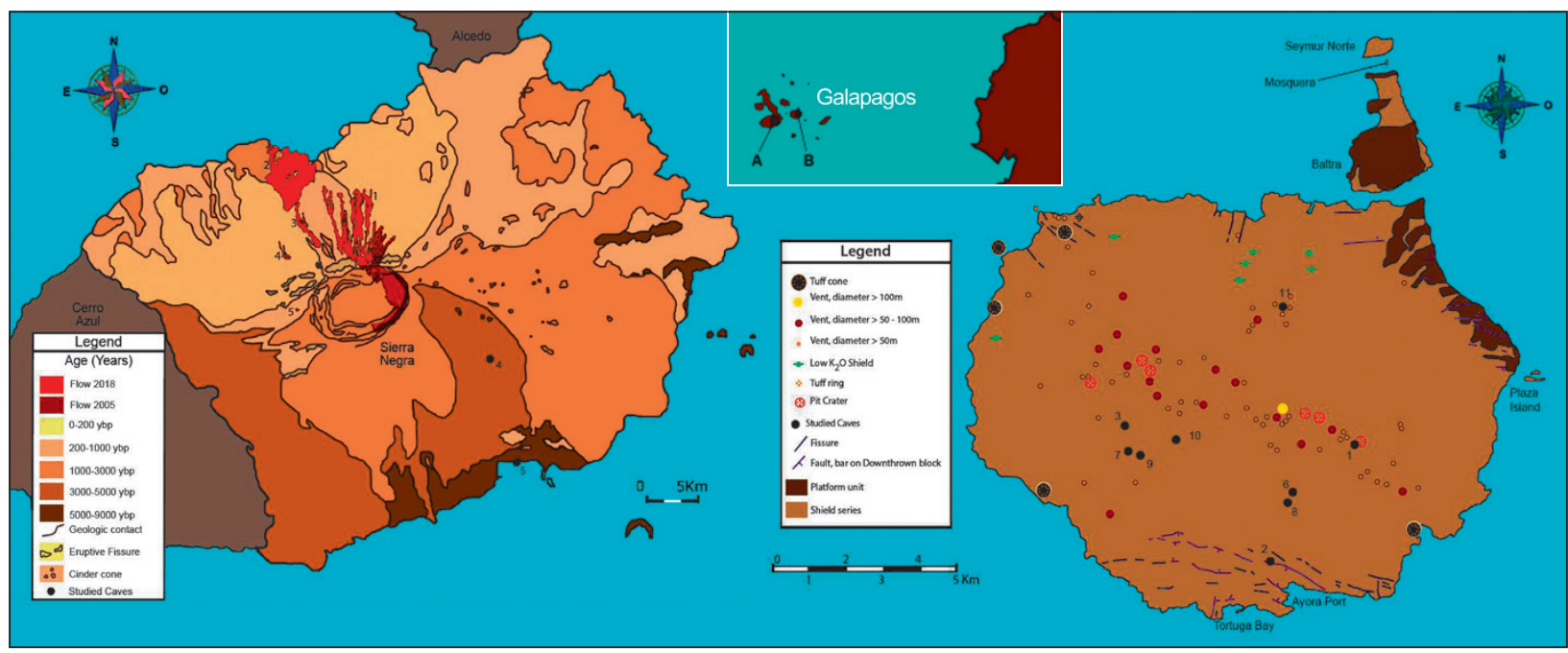

Fig. 1: General situation of the Galápagos Islands (center) and the geological maps of (left) southern Isabela Island and (right) Santa Cruz. Pins locate the caves visited during this study; numbers refer to Tab. 1. (maps based on Toulkeridis 2013). 


\section{PYRODUCTS}

Within the family of lava caves or, perhaps more accurately, volcanic rock caves, (for an overview see Kempe 2002, 2019), we find both primary and secondary caves. The second group contains sea-caves, caves formed by the erosion of water and tectonic caves. Of these, we visited "La Grieta" an impressive, seawater-filled graben with associated fissure- and talus-cavities in the proximity of Puerto Ayora, the main port of the island of Santa Cruz. All other caves visited are primary caves, i.e., vents (Triple Volcán on Isabela) or "pyroducts". "Pyroduct" (Lockwood \& Hazlett 2010, pp. 138ff), colloquially also called "lava tube", "lava tunnel", or "lava pipe", is "a term coined by an eye-witness [i.e., the missionary Titus Coan (1844)] describing active subterranean 'rivers of fire' during the 1843 eruption of Mauna Loa. Pyroducts come in many shapes and sizes (few of them "tubular") and form in many different ways....". They can be defined as ".... any internal lava conduit in a flow, irrespective of shape and size, regardless of whether it contains molten lava during eruptive activity or is preserved as an elongate cave after eruptive activity ends and molten rock drains away. Etymologically, the word pyroduct ("fire conduit") could also describe surface lava channels, but we shall restrict the term only to describe subsurface features...".

Therefore, pyroducts are of prime importance in understanding the architecture of basaltic island shield volcanoes, basaltic intracontinental lava fields and hotspot volcanics (e.g., Calvari \& Pinkerton 1998). Without pyroducts, extremely long lava flows could not come into existence. The recent eruption of the E-Rift of the Hawaiian shield volcano Kilauea 1983-2018 (known as the Pu'u 'Ōō-Kūpaianaha eruption) (Wolfe 1988; Heliker et al. 2003) allowed the study of some aspects of pyroduct genesis and function. Episodes 48 and 50 to 53 (Helz et al. 2003) formed 12 to $14 \mathrm{~km}$ long pyroducts issuing lava to the ocean. A few of the conduits are still accessible. $\mathrm{MgO}$-content of quenched glasses measured on samples from the Kūpaianaha lava pond and on pyroduct samples taken at skylights or at the ocean front indicated that the temperature of the lava dropped only about $0.6{ }^{\circ} \mathrm{C}$ per $\mathrm{km}$. Similarly, temperature measurements through skylights showed a temperature loss of about $1^{\circ} \mathrm{C}$ per $\mathrm{km}$ (reviewed by Kauahikaua et al. 2003). Thus, closure of a primary roof across flowing lava is probably one of the most important
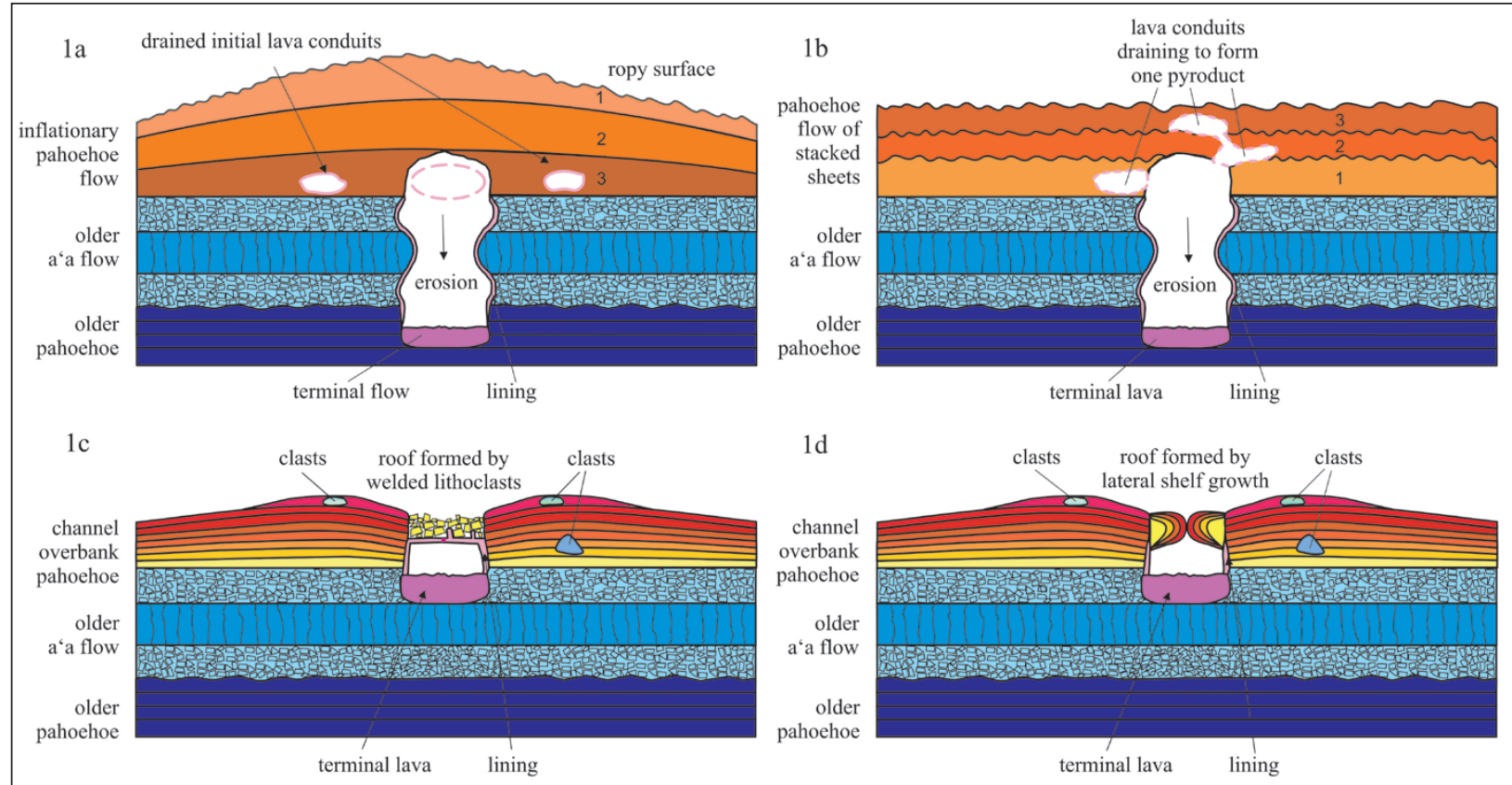

Fig. 2: Schematic cross-sections of the four models of pyroduct formation known so far. The amount of erosion shown can be quite variable, even within the same pyroduct. Also, the underlying strata does not necessarily need to be an 'a'a flow. Cross-section 1a shows the "inflationary mode" where the roof sheets are oldest at the top and youngest at the bottom. There several ducts can develop in parallel that are drained once one of them cuts down, collecting all of the flowing lava into one bed. Cross-section $1 b$ illustrates pyroduct formation by "confluence" of lava from several small conduits within lava sheets deposited on top of each other. Here the oldest lava sheet is at the bottom and the youngest on top. All the flow in these ducts converge and erode an underlying lava flow, preferentially an easily erodible layer of 'a' rubble. Cases 1c and 1d illustrate the "crusting over of a channel". This can either happen by the jamming and welding offloating clasts (1c) or by the slow accretion of shelves and roof-closure across a channel along a central suture (after Kempe 2012). 
processes in providing thermal insulation of the flowing lava resulting in the extended flow and further development of any pyroduct. The recent experiences from Hawai $\mathrm{i}$ and elsewhere imply that pyroducts are able to be formed by at least four different processes (Kempe 2012). Two of them, involving "inflation" (Hon et al. 1994) and "confluence" (Bauer 2011; Bauer et al. 2013) arise from pāhoehoe flows containing proto-ducts, while the other two processes are associated with the freezing-over of lava-channels. This can be achieved by the inward growth of benches of by the welding of floating clasts. Both of these roof-closing mechanisms were documented for pyroducts associated with the Etna eruption of 1991-93 (Calvari \& Pinkerton
1998). Due to the unusual steep slope of Mount Etna of up to $30^{\circ}$ pyroducts also form there within the core of 'a' $\mathrm{a}$ flows, so far a phenomenon not documented in Hawai'i. Hawaiian experience however shows that the first type, the formation of a pyroduct by inflation, is most probably the main process involved in the initiation of a long-lived pyroduct (Fig. 2). The $16^{\text {th }}$ International Symposium on Vulcanospeleology gave an opportunity to test how these Hawaiian models as well as experiences and field observations gathered in different volcanic areas worldwide would apply to another important basaltic island volcano group (McBirney \& Williams 1969; White et al. 1993; Toulkeridis 2013 and references therein).

\section{INVESTIGATING GALÁPAGOS CAVES; MATERIALS AND METHODS}

Constantin et al. (2018) briefly refer to the research history of Galápagos and the number of caves known, totaling 57 (29 on Santa Cruz, 4 on Isabella and 14 on five other islands). Of these we discuss $\mathrm{f}$ nine pyroducts that were investigated prior to and during the symposium (Fig. 1): Cueva del Cascajo, Cueva de Gilda and Gallar-

Tab. 1. General observations concerning the lava caves visited ("puka" is Hawaiian for "hole").

\begin{tabular}{|c|c|c|c|c|c|c|c|c|}
\hline No & Group 1 & Thin Roof & Downcutting & $\begin{array}{l}2^{\text {ndary }} \\
\text { Ceilings }\end{array}$ & Lavafalls & Pukas & Oxbows & Stage \\
\hline 1 & $\begin{array}{l}\text { Cueva del } \\
\text { Cascajo } \\
(3,010 \mathrm{~m})\end{array}$ & $\begin{array}{l}\text { Thin, one sheet } 0.8 \text { to } \\
1.5 \mathrm{~m} \text { thick with shear- } \\
\text { induced vesicle layers }\end{array}$ & $\begin{array}{l}\text { Substantial (>10 } \\
\text { m), canyon-like }\end{array}$ & $\begin{array}{l}\text { Mostly one, } \\
\text { but sometimes } \\
\text { up to } 5\end{array}$ & $\begin{array}{l}\text { At least four } \\
\text { major }\end{array}$ & $\begin{array}{l}\text { Variety } \\
\text { of pukas }\end{array}$ & Two small & 3 \\
\hline 2 & $\begin{array}{l}\text { Mirador de los } \\
\text { Túneles } \\
(929 \mathrm{~m}) \\
\end{array}$ & Thin, one thick sheet & Substantial & None & $\begin{array}{l}\text { None in } \\
\text { western part }\end{array}$ & \begin{tabular}{|l|} 
Five (two \\
in side \\
branch) \\
\end{tabular} & $\begin{array}{l}\text { One } \\
\text { substantial }\end{array}$ & 3 \\
\hline 3 & $\begin{array}{l}\text { Cueva de } \\
\text { Premisias } \\
(431 \mathrm{~m})\end{array}$ & $\begin{array}{l}\text { One thick or several } \\
\text { thin sheets }\end{array}$ & $>11 \mathrm{~m}$ & $\begin{array}{l}\text { One at current } \\
\text { exit }\end{array}$ & None & Two & None & 2 \\
\hline 4 & \begin{tabular}{|l|} 
Cueva de Sucre \\
$(339 \mathrm{~m}) 5$ \\
\end{tabular} & \begin{tabular}{|l|} 
One thick or several \\
thin sheets \\
\end{tabular} & Small (less $<1 \mathrm{~m}$ ) & None & None & One & \begin{tabular}{|l|} 
Multiple- \\
trunked \\
\end{tabular} & 3 \\
\hline \multirow[t]{2}{*}{5} & $\begin{array}{l}\text { Túnel del Estero } \\
(90 \mathrm{~m})\end{array}$ & One sheet & None & None & None & None & None & 1 \\
\hline & Group 2 & Thick Roof & Downcutting & $\begin{array}{c}2^{\text {ndary }} \\
\text { Ceilings }\end{array}$ & Lavafalls & Pukas & Oxbows & \\
\hline 6 & $\begin{array}{l}\text { C. de Gilda } \\
(410 \mathrm{~m})\end{array}$ & Not clearly visible & $\begin{array}{l}\text { Several meters, } \\
\text { cave slot-like }\end{array}$ & Only at lava fall & One & One & None & 2 \\
\hline 7 & $\begin{array}{l}\text { Tortoise Junction } \\
\text { tourist cave } \\
\text { (203 m) }\end{array}$ & $\begin{array}{l}\text { Multiple small 'a'ā } \\
\text { flows, primary roof } \\
\text { removed }\end{array}$ & Several meters & Two & None & One & None & 2 \\
\hline 8 & $\begin{array}{l}\text { Cueva de } \\
\text { Gallardo } \\
(2,316 \mathrm{~m})\end{array}$ & $\begin{array}{l}\text { Very thick, primary } \\
\text { roof one sheet, } 0.8 \mathrm{~m} \\
\text { thick with several m of } \\
\text { thin 'a'ā flows above }\end{array}$ & Several meters & None & $\begin{array}{l}\text { Several } \\
\text { "cascades" }\end{array}$ & $\begin{array}{l}\text { Four, } \\
\text { lining } \\
\text { collapse }\end{array}$ & Two & 3 \\
\hline 9 & $\begin{array}{l}\text { Cueva de Chato } \\
1 \\
(515 \mathrm{~m})\end{array}$ & $\begin{array}{l}\text { Very thick, primary } \\
\text { roof } 0.5-1 \mathrm{~m} \text { thick, } \\
\text { with several m of 'a'ā } \\
\text { flows above it. Primary } \\
\text { roof largely eroded }\end{array}$ & 1 to $2 \mathrm{~m}$ & None & None & Three & Many & 3 \\
\hline 10 & $\begin{array}{l}\text { Cueva de Royal } \\
\text { Palm } \\
(1,040 \mathrm{~m})\end{array}$ & $\begin{array}{l}\text { Very thick, primary } \\
\text { roof possibly removed, } \\
\text { with several thick 'a'ā' } \\
\text { flows above }\end{array}$ & $>5 \mathrm{~m}$ & Several & One & Two & One & 3 \\
\hline 11 & $\begin{array}{l}\text { Cueva La Llegada } \\
(2,066 \mathrm{~m})\end{array}$ & Very thick, 0.8-1.25 m & $\begin{array}{l}\text { Substantial, }>8 \\
\mathrm{~m} .\end{array}$ & $\begin{array}{l}\text { Variable, up } \\
\text { to } 3\end{array}$ & Multiple & $\begin{array}{l}\text { Many } \\
\text { Pukas }\end{array}$ & None & 3 \\
\hline
\end{tabular}


do, Mirador de los Túneles (Cueva de Kübler), Cueva de Chato 1, Cueva de Royal Palm, Tortoise Junction tourist cave, Cueva La Llegada and Cueva de Premisias on Santa Cruz Island and Triple Volcán, Cueva de Sucre and Túnel del Estero on Isabella Island. In addition, detailed surveys were conducted in Mirador de los Túneles/Cueva de Kübler and in the upper $150 \mathrm{~m}$ of the Cueva del Cascajo. There a Leica Disto was used to determine length and inclination and a Silva compass to measure azimuth. The grid was calculated with a self-written Excel routine. Otherwise photographs and notes were taken, and the morphology and outcrops discussed by a number of participants. Addison (2011) published maps of the Triple Volcán vent, of the Cueva de Sucre and of the Túnel del Estero.

\section{RESULTS}

The pyroducts visited can be subdivided into two groups; those that have a roof composed only of their thin primary roof and those that have a very thick roof composed of the original primary roof and later thin 'a'a surface flows (Tab. 1).

\section{THE PRIMARY ROOF - OBSERVATIONS}

The first group of caves has a thin roof structure. The primary roof of Cascajo Cave, for example, is composed

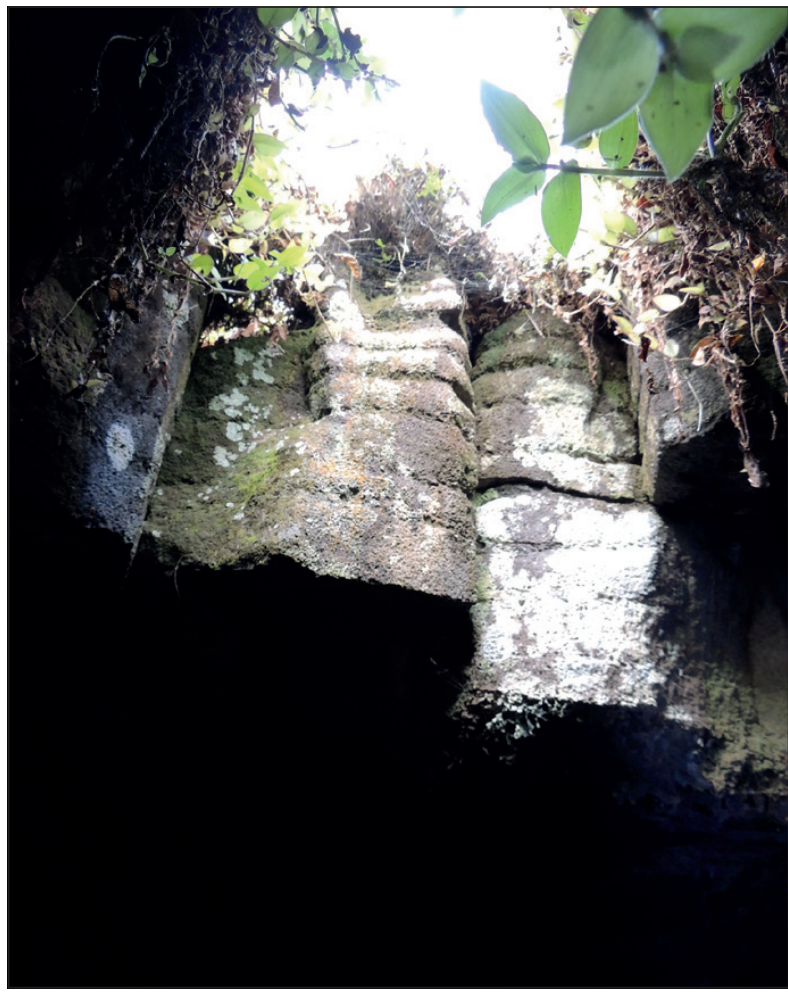

Fig. 3: Cross-section of pähoehoe sheet forming the primary roof of the Cueva del Cascajo. Note the presence of horizontal vesicle concentrations along which the layer may have slipped when hot (Photo: S. Kempe). of only one sheet (Fig. 3) between $0.6 \mathrm{~m}$ and over $1 \mathrm{~m}$ thick. This sheet is textured by several horizontal zones of high vesicle concentration. Along these planes there is structural evidence of slippage on the lower face. Furthermore, the vesicles in these planes are not vertically oriented, but demonstrate horizontal elongation.

The second group of caves have thicker roofs with more complex structure. These have a thick primary roof with multiple additional thin 'áa layers. Thick, massive layers with low vesicularity are observed. These can be bounded with rubble above and below. A notable example of this is in Cueva de Gallardo, beyond the lowest puka. A cold collapse (i.e., a collapse long after the activity in the duct has subsided) has opened the roof for closer inspection (Fig. 4). There we are able to note the primary roof as it stretches across the cave. The roof is parted by vertical contraction cracks and by horizontal separations along vesicle concentrations. Above this layer, an 'áā flow is observed with its typical tripartite structure: a central, thick and massive core of low vesicularity, accompanied by rubble layers below and above. Above this, and forming the cave roof up to the present day, is the inferior side of another 'a'à flow.

Information about the structure of the primary roof is of importance if building across or near to a lava cave is planned. For example, driving a bulldozer across the roof of of Cascajo Cave may turn out to be fatal. JordáBordehore \& Toulkeridis (2016) and Jordá-Bordehore et al. (2016) discuss engineering considerations and roof stability of lava caves. 


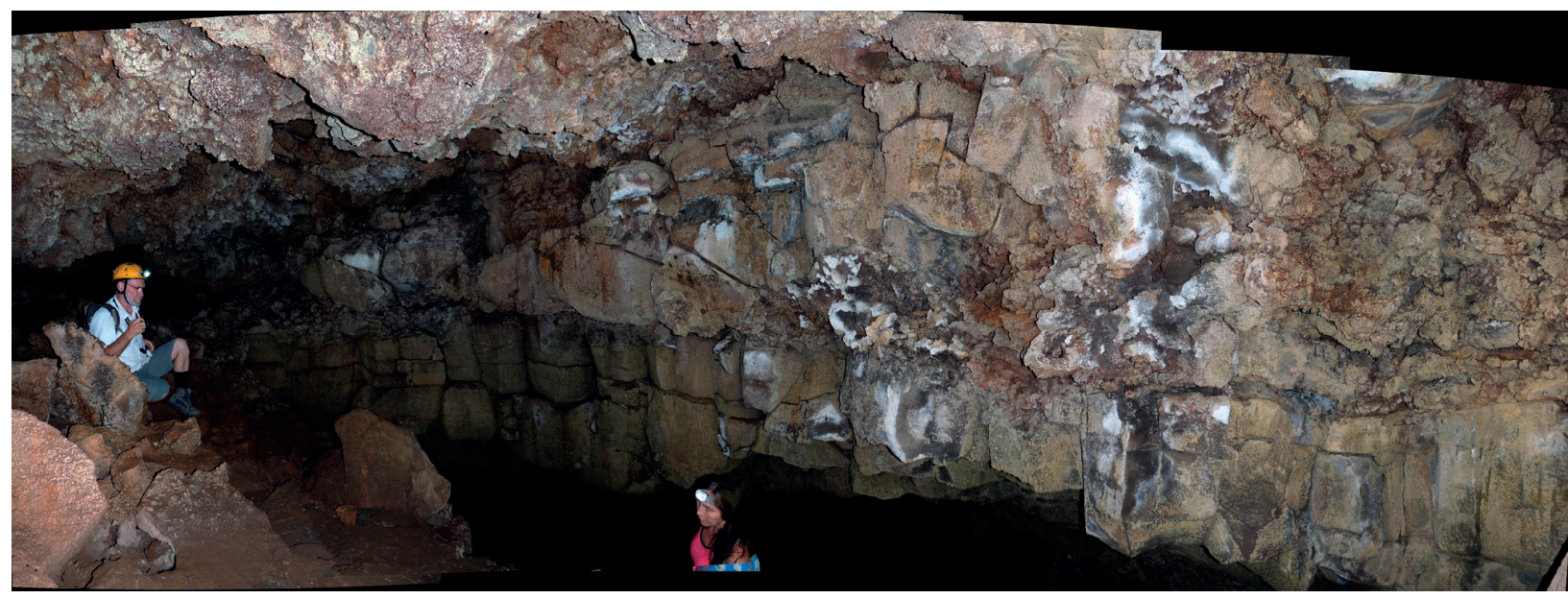

Fig. 4: Panorama of a roof collapse of Cueva del Gallardo below its last puka downhill. Here the meter-thick primary roof is still intact (right lower layer) overridden by an irregular 'a'à flow that also collapsed and a second 'a'a flow that forms the roof (Photo: S. Kempe).

\section{THE PRIMARY ROOF - DISCUSSION}

These characteristics suggest that the first group of caves has a simple development. They form when a pāhoehoe sheet quickly covers the ground, solidifies and degasses, forming vesicles inside. The layer then becomes less dense and the hot, fluid lava of the next pulse can creep below it, "inflating" the first sheet. Interestingly we could not find examples of multiple inflation sheets such as described from Whitney's Cave (Kempe et al. 2010) or the Huehue Cave (as described in Model 1, Fig. 2a). The evidence of slippage suggests that flowing lava underneath was in direct contact dragging on the lower side of the roof. The elongated vesicles are further indicators that the sheet has been exposed to differential drag. It appears that the surface structure of the pāhoehoe sheet has been lost due to bioturbation (i.e., rocks turned over by uprooted trees) and a cover of ash-derived reddish soil. Therefore, it remains uncertain whether the roof-sheet displayed a ropy structure.Explaining the roof structure of the second group of caves is more difficult. In order to unravel the development of the roof structure of the second group of caves one needs to assume that the primary roof has been, after its establishment and following the initiation of the underlying pyroduct, modified by surface lava flows (Fig. 5). Given time, this most likely would be the fate of any primary roof as later eruptions would bury it over the eons. However, in these cases, these later flows are in part forming the cave's roof with the primary roof missing. Thus, these flows must have been emplaced by the same eruption that fed the pyroduct. In that situation the roof might grow many meters thick, finally overloading the primary roof. The eventual roof collapse would be assimilated by the flowing lava in the pyroduct and possibly carried away. This process is capable of explaining why we observe large irregular halls with roofs formed by welded 'a'à or the massive layers of 'aa à core layers such as observed in Chato I. In the case of Cueva de Gallardo, the primary roof survived the loading by additional surface flows, but further uphill, where the entrance puka separates the lower and the upper part of the Cueva del Gallardo (and separating them into actually two caves, albeit of the same pyroduct), the primary sheet must have collapsed and been carried out during activity. Thus, today we enter the cave (both downhill and uphill) through large halls. These halls are taller and also much wider than the original pyroduct, convincing evidence of collapse and upward enlargement during the pyroduct's activity.

\section{INTERNAL FEATURES OF PYRODUCTS}

Tab. 1 shows that many other internal features that are found in Hawaiian caves, are also present in Galápagos, namely evidence of downcutting, lavafalls, secondary ceilings (septa) and braiding (i.e., the presence of oxbows).
It is not self-evident that these features would be present. For example, in the Jordanian lava caves in the Harrat Al-Shaam, no lavafalls have yet been found, evidence of downcutting is inconclusive, secondary ceilings are absent and even braiding is seen only once (Kempe 
et al. 2012). Similarly, the lava caves at Undara, Australia, do not show any of the above-mentioned features (Middleton \& Kempe in press). As it happens, these two sites are intracontinental lava fields and not island shield volcanoes like the ones in Hawaici and the Galápagos. However, this difference is not a sufficient explanation for such behavior and will need future consideration.

Braiding is a feature established earliest in the development of a lava conduit (embryonic braiding; Allred \& Allred 1997). It apparently comes about when several flow paths are established beneath the primary roof. The conduits with the lower flow-rate and those that are higher in elevation are drained first while the later trunk passage cuts down. Thus, these passages, if they are not filled by lava surges, generally form low mazes near the ceiling of the final cave. Fig. 6 shows a short oxbow in the upper passage of Cueva del Cascajo.

Evidence of these higher passages being filled is occasionally seen where cross-sections are exposed through erosive or melting processes, or where outflows of molten lava from the filled passage dripped down into the trunk passage resulting in various forms of secondary lava for- mations, such as sheet flow on walls, stalactites and stalagmites. This described process provides a fundamental role in the formation of a variety of lava rock speleothems (e.g., Kempe 2013).

Downcutting is one of the most basic processes in pyroducts. The first, undebatable evidence has been observed in Earthquake Cave, Hilina Pali, Kỉlauea, Hawaii (Kempe \& Ketz-Kempe 1992a, b). There the lining of the conduit fell off, revealing an ash layer (stratigraphically identified as Pahala Ash). Since ash clearly is not forming an integral part of a lava flow, its outcropping in the wall of a pyroduct is a clear proof of "thermal downcutting" and the cave has been used in a model of this process by Greeley et al. (1998). Since then many other sites have been discovered and most of the pyroducts (beyond the simple braiding stage) have evidence of downcutting as, for example, demonstrated for Kazumura Cave, Hawai $i$ (Allred \& Allred 1997). Downcutting becomes recognizable where the lining falls away revealing 'a'a rubble behind. Such sites were discovered in all of the caves listed in Tab. 1 apart from Cueva de Sucre and Túnel del Estero (see also Fig. 7).

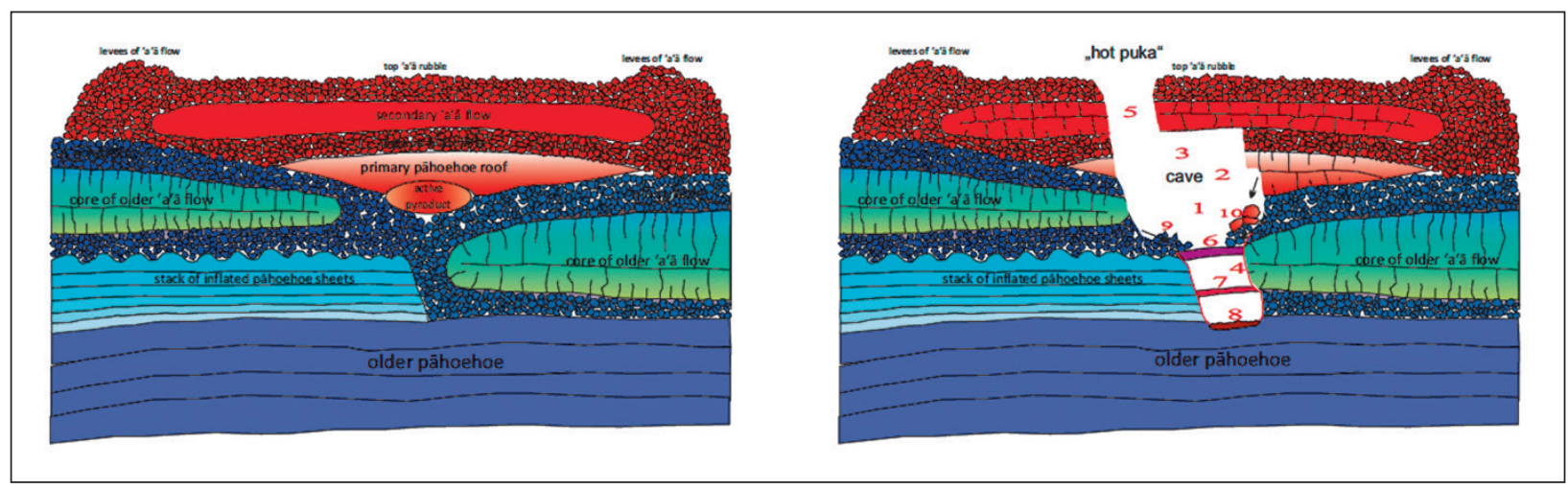

Fig. 5: Scheme of the evolution of a cave with a complex roof.

Left: A pyroduct (red oval) is established in the depression between two older 'a'a flows (in blue). In turn, these are underlain by a stack of inflationary pähoehoe sheets (with a ropy surface) and a massive older pähoehoe stack (all blue as an indication that they are cold). The pyroduct was established with only one pähoehoe sheet (reddish). Later, but during the same eruption and while the pyroduct is still active, a massive 'a' $\mathrm{a}$ flow covers the area (red).

Right: Now the pyroduct is well isolated thermally and starts to cut down. First the underlying 'a'a rubble from the older flows is removed and a wide cave is created (1). This destabilizes the roof and the pähoehoe sheet collapses and is carried out (2). Next the bottom rubble of the transgressing 'a'a flow collapsed and is carried out as well (3). Only a thin layer a rubble, welded to the 'a'a core remains so that it looks as if the roof of the cave is formed by 'a'à rubble. Further downcutting into the core of one of the underlying 'a'a flows narrows the cave to a canyon. Along its sides, a glassy lining covers the walls (thick red line; 4). The deepening canyon, in which the lava flows at its bottom, allows the 'a' core, still forming the cave's roof, to cool quicker. Shrinkage cracks form. This eventually leads to the collapse of a skylight, called a "hot puka" because it occurred during activity and its collapse material is removed by the flowing lava (5). The opening allows colder air to enter and a secondary ceiling to solidify on top of the active flow at the bottom of the canyon (6). Further downcutting into the bottom 'a'a rubble of the older underlying flows creates again a gas space above the actively flowing lava and a lower secondary ceiling solidifies (7). Finally, the eruption ceases and the lower passage is evacuated. Only a thin layer of welded terminal 'a'a remains in the cave (8). Further collapse of 'a' $a$ rubble from the walls (9) and further collapse of the primary roof (10) collect on top of the upper secondary ceiling. In the end, the cave (in this schematic evolution) has three levels, separated by two internal secondary ceilings (septa). The upper passage, with a welded 'a'à rubble ceiling and loose 'a'à rubble and other breakdown blocks at its bottom now does not resemble its original pyroduct anymore. The graphic combines observations made mainly in Cueva del Cascajo and Cueva del Gallardo. 
The mechanisms causing the rapid downcutting in a pyroduct still remain a matter of debate. Mechanical and thermal processes may act either alone or in unison. Mechanical erosion, for example, can relatively rapidly erode through ash lavers, paleosols or loose 'áa rubble. When it comes to cut through the core of an 'á flow, melting seems to be the option. Melting would consume a large amount of energy, cooling the flow. Melting, however, only needs to be partial, since only the glassy parts of the basalt need to be fluidized, while phenocrysts can be plucked from the partial melt by the drag of the flowing lava. Meter-sized scallops, caused by the turbulent remelting of 'a'a blue-rock have been observed occasionally, sustaining such a model. Remelting seems to be achievable since pyroducts appear to be active for weeks and months as documented for the last Kilauea eruption (Kauahikaua et al. 2003) or the historic Mount Etna eruptions (Calvari \& Pinkerton 1998, 1999). With flow rates of several cubic meters per second, enough thermal energy may be available to explain the observed downcutting through massive 'a'à cores.

One of the means by which erosion seems to work is the lavafall (Allred \& Allred 1997; Kempe 1997). Erosion is present in several of the visited caves. Fig. 8 demonstrates a lavafall in Cueva del Gilda. There the fall did not develop a specific morphology, such as some of the large falls in Kazumura Cave that have generated huge plunge pool rooms. In many cases one can observe semi-vertical shelves that mark former positions of the lavafall, illustrating that the lavafall has migrated substantially uphill. Again, the question arises, how exactly a lavafall is developed. It might be mechanical, with the falling lava hammering at the floor and thereby undermining the foot of the lavafall. The cascading lava would be able to abrade the face of the fall. On the other hand, the falling lava would also be capable of melting the fall's face more readily due to the large lava velocity thinning the boundary layer between the flowing lava and the underlying rock.
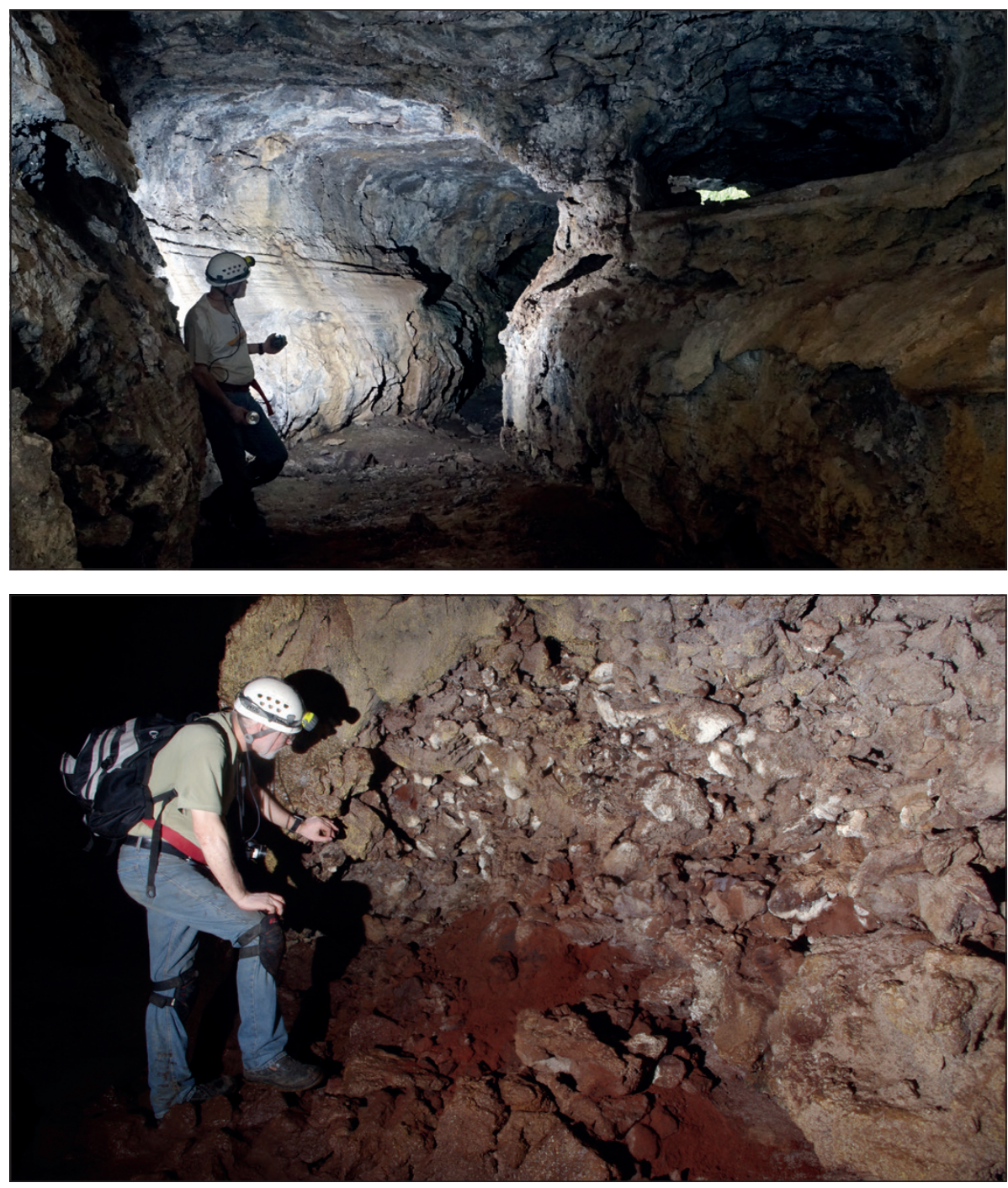

Fig. 6: View of a short, braided passage (or "oxbow") in Cueva del Cascajo, upper passage, near Station Z19, viewing downhill. The right-hand side was drained as the main passage on the left cut down. Note Puka 2 of the cave in the background. The floor of the main passage is a secondary ceiling with an over $5 \mathrm{~m}$ deep passage below it (Photo: G. Middleton).

Fig. 7: Cueva del Premisias: The lining (behind and above person) has fallen away, revealing an 'a'a rubble layer that transgressed a paleosol, oxidized by the transgressing 'a' $\bar{a}$ flow. Above the 'a' rubble part of the 'a'a core is visible (Photo: H. Marinakis). 


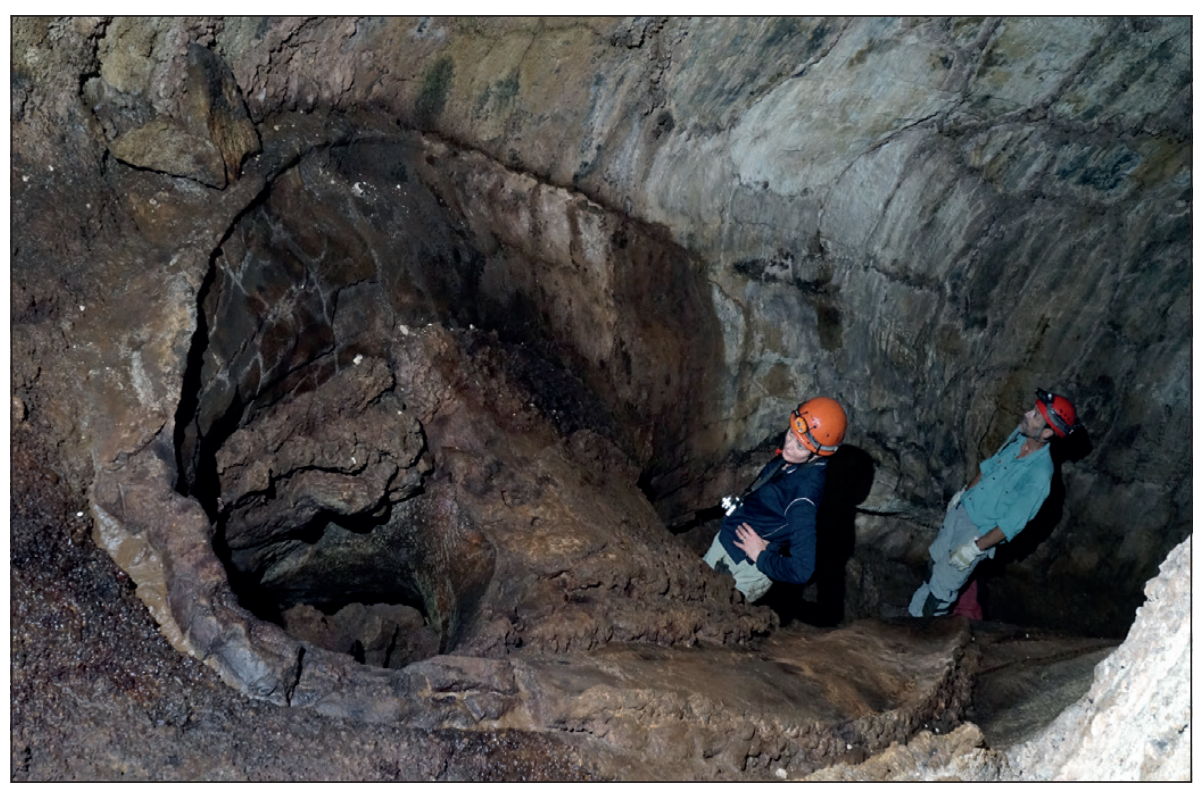

Fig. 8: A 1 m-high lava fall in Cueva del Gilda (Photo: G. Middleton).

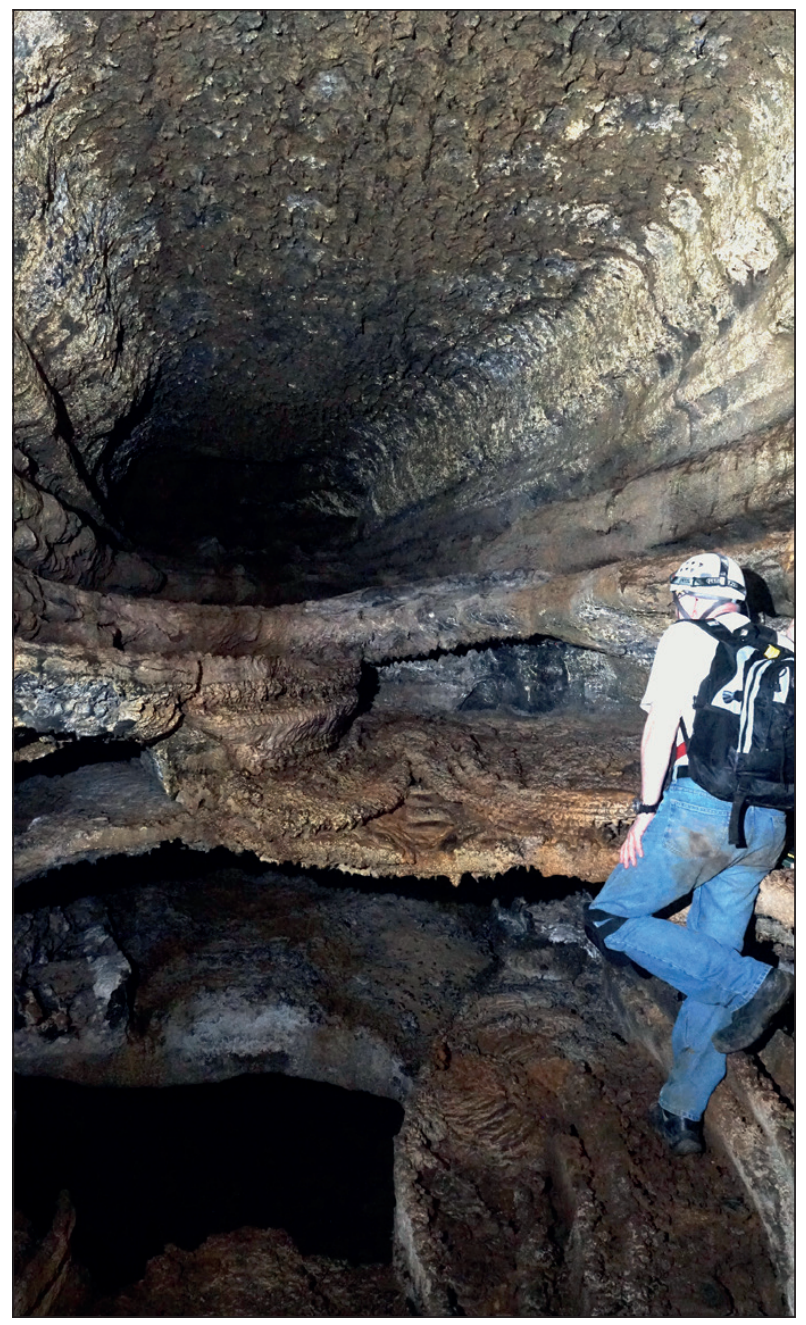

Fig. 9: View uphill from Puka 4 into the Cueva del Cascajo showing several secondary ceilings at various levels (Photo: G. Middleton).
As the downcutting proceeds, the initially oval- or half-oval-shaped conduit becomes rectangular in crosssection with lava flowing at its base. It then appears to function as an underground canyon with a gas space above the flowing lava river. Any change in the energy balance of the pyroduct can consequently cause the renewed formation of a roof on top of the lava river, i.e., splitting the canyon into a lower, active pyroduct and an upper inactive, gas-filled passage. In the literature (e.g., Calvari \& Pinkerton 1999) the existence of secondary ceilings (septa) is sometimes misinterpreted as evidence for two independent conduits on top of each other. This does not make sense because a younger pyroduct would never be emplaced exactly on top of an existing conduit. The younger flow would always stay to the side of the previous conduit and its morphological ridge.

Further downward erosion may repeat the process, leaving several secondary ceilings above each other (Fig. 9). In most cases the energy balance is disturbed by the local collapse of the primary roof, forming an opening (in Hawai'i called a puka). Then hot gas may escape from the cave and cold air might enter. This causes to solidify a septum below and downhill of the puka due to the fact that hot gas rises. If two pukas open, then relatively long secondary septa may form between them. They would start at the lower puka and continue uphill as long as there is a temperature difference. The heated air/gas mixture would then rise from the upper puka like fumes from a chimney. Alternatively, it is conceivable that in deeper canyons the energy balance may be disturbed enough to cause to solidify the surface of the lava river without any pukas in operation. The secondary ceiling is sometimes re-enforced by spills from uphill up to the point that the entire space of the passage above is filled. Tab. 1 indicates 


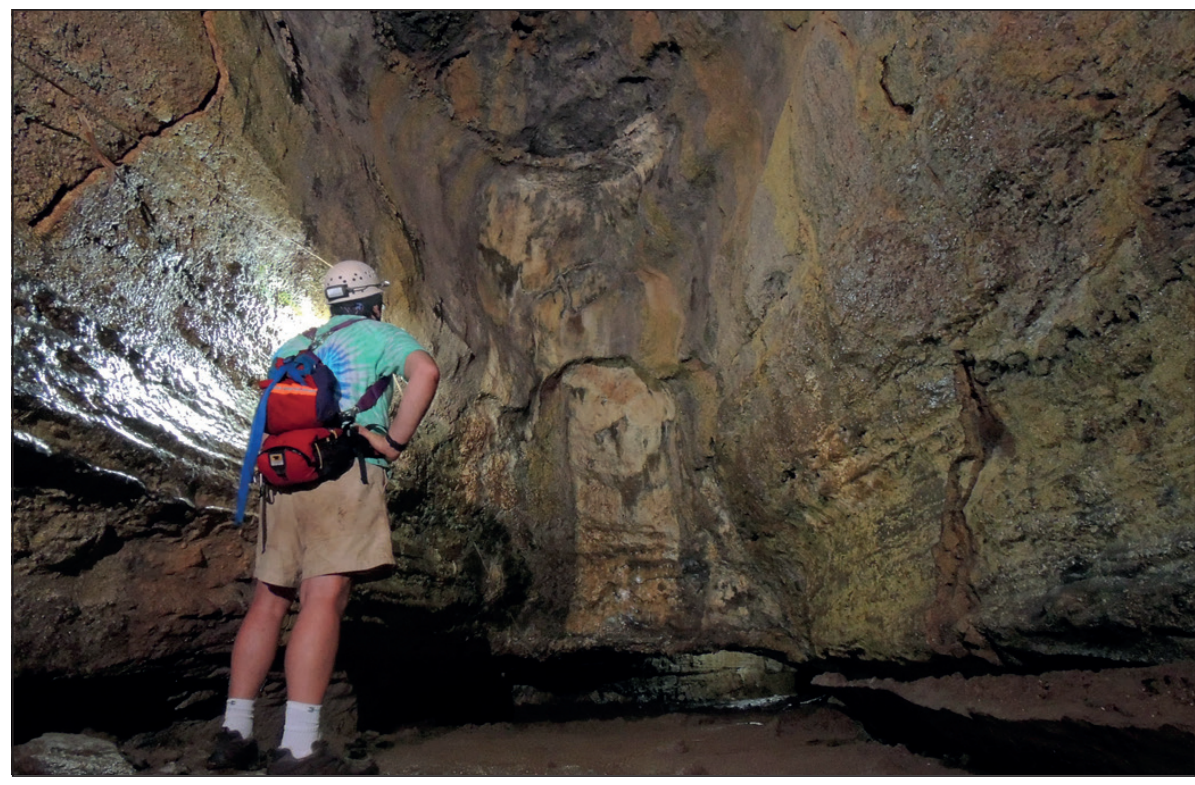

Fig. 10: The uphill termination of the canyon of Cueva de Premisias (Photo: S. Kempe).

that several of the caves visited on Galápagos have secondary ceilings (e.g., Fig. 9).

The most enigmatic case of a secondary ceiling has been encountered in Cueva de Premisias. There, the up to $12 \mathrm{~m}$ high canyon ends abruptly uphill in front of a vertical wall (Fig. 10) with only an opening of about $3 \mathrm{~m}$ wide and $1 \mathrm{~m}$ high at its base. This has been the cross-section of the lava river in the final stage of the cave development. The wall above appears to be solid, just textured by two cupola-like half-spheres that may have formed by melting due to hot gases convecting upward from the lava issuing from the constriction. Behind the constriction, the secondary ceiling rises slowly towards the exit, a relatively small puka. This rise may have caused a ponding of the lava causing an overflow onto the secondary ceiling. Looking back from the puka downhill there is indeed no open space above the secondary ceiling. The former upper passage appears to be entirely filled with lava. This seems to be a plausible explanation of the situation, applying the rules deduced so far. However, it may not be the only explanation.

\section{CUEVA DEL CASCAJO, A CASE STUDY}

In 1990/1991 Spanish speleologists explored and surveyed Cueva del Cascajo, at that time the longest cave in the Galápagos and in all of South America (Hernández et al. 1992). Unfortunately, the published map is lacking internal details. Due to the extensive presence of secondary ceilings, the exact length is not known yet, but the cave is reported to be about $3 \mathrm{~km}$ long. Fig. 11 shows the upper $150 \mathrm{~m}$ of Cueva del Cascajo (Z-series linked to Y-series at Y14) which was surveyed during this study. It appears to be one of the most interesting and complex sections of this cave. Small inaccuracies in the measurement of the inclination lead to the fact that the bottom of the upper passage (see longitudinal section) is nearly overlapping with the ceiling of the lower passage.

Throughout the entire length of the cave shown on the map, the passage is divided by a secondary ceiling. The lower passage is divided by further ceilings.
The upper passage with three pukas, marks the original level at which the cave has been formed. Puka 1 is a trench that gives access to the upper passage down a small breakdown slope. There the primary roof is composed of only one sheet, being $0.6 \mathrm{~m}$ thick. The uppermost secondary ceiling forms the floor of the passage that opens up to walking size. On the left (coming from the entrance), the lining of the pyroduct has fallen away, revealing 'a'a rubble The passage makes two relatively sharp bends, first to the right, then to the left, resuming its overall ESE course. Across from station Z20, the 'a 'a is poorly welded and after moving some of it, a hole, communicating to the lower passage, was opened. At station Z19 a pillar is encountered (Fig. 6). The southern passage is well above the floor of the main passage, marking the original level at which the cave formed. Beyond, ca. $50 \mathrm{~m}$ from Puka 1, Puka 2 opens up. It sits off-center above the 


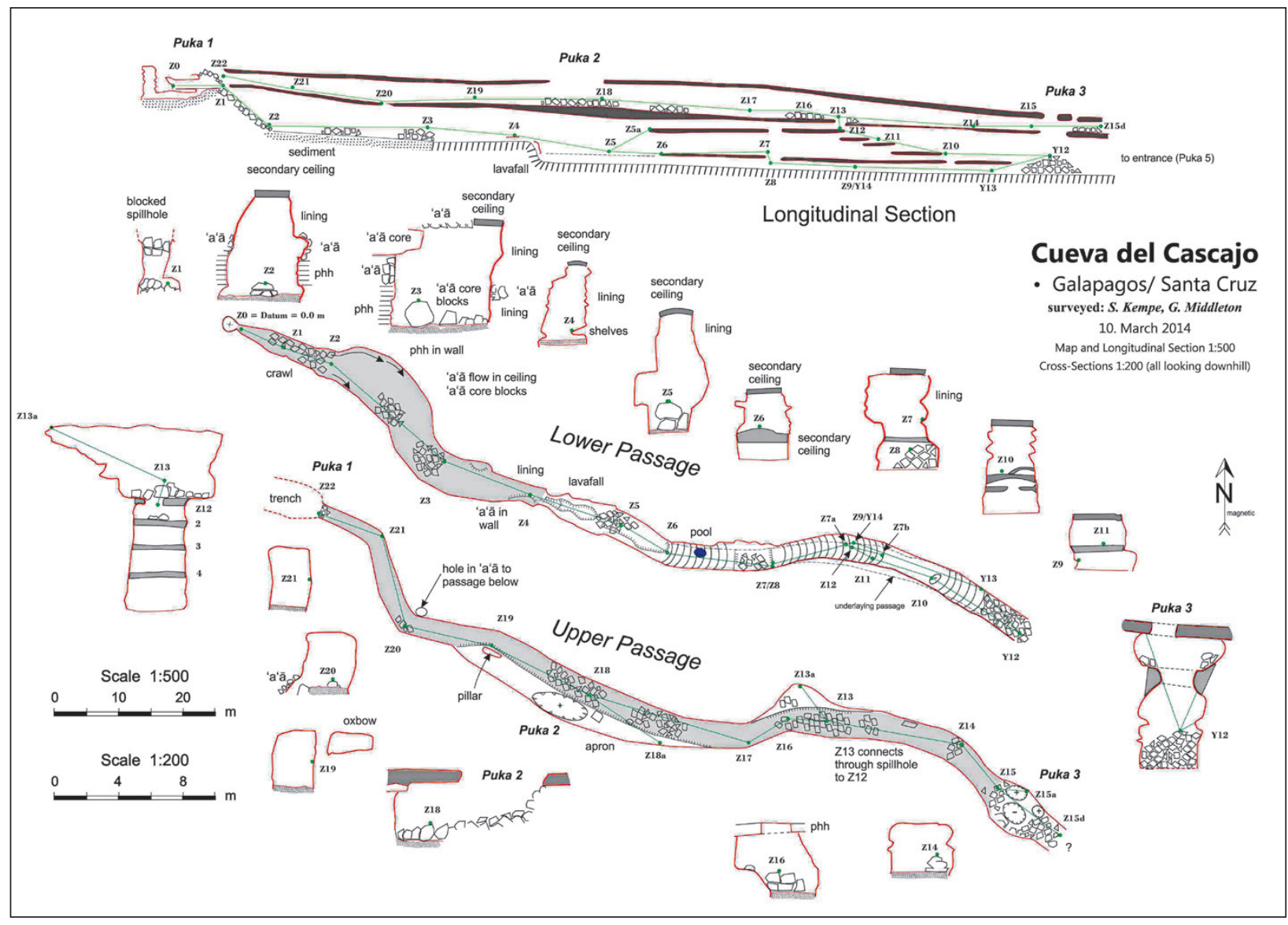

Fig. 11: Map, cross-sections and longitudinal section of the upper $150 \mathrm{~m}$ of Cueva del Cascajo. Shaded areas in ground plan mark sediment cover. Grey shading marks secondary ceilings in cross sections and longitudinal section and dark gray shadings marks the primary ceiling in cross-sections. Red lines mark outer walls, green lines and dots mark survey lines and stations (survey by S. Kempe and G. Middleton).

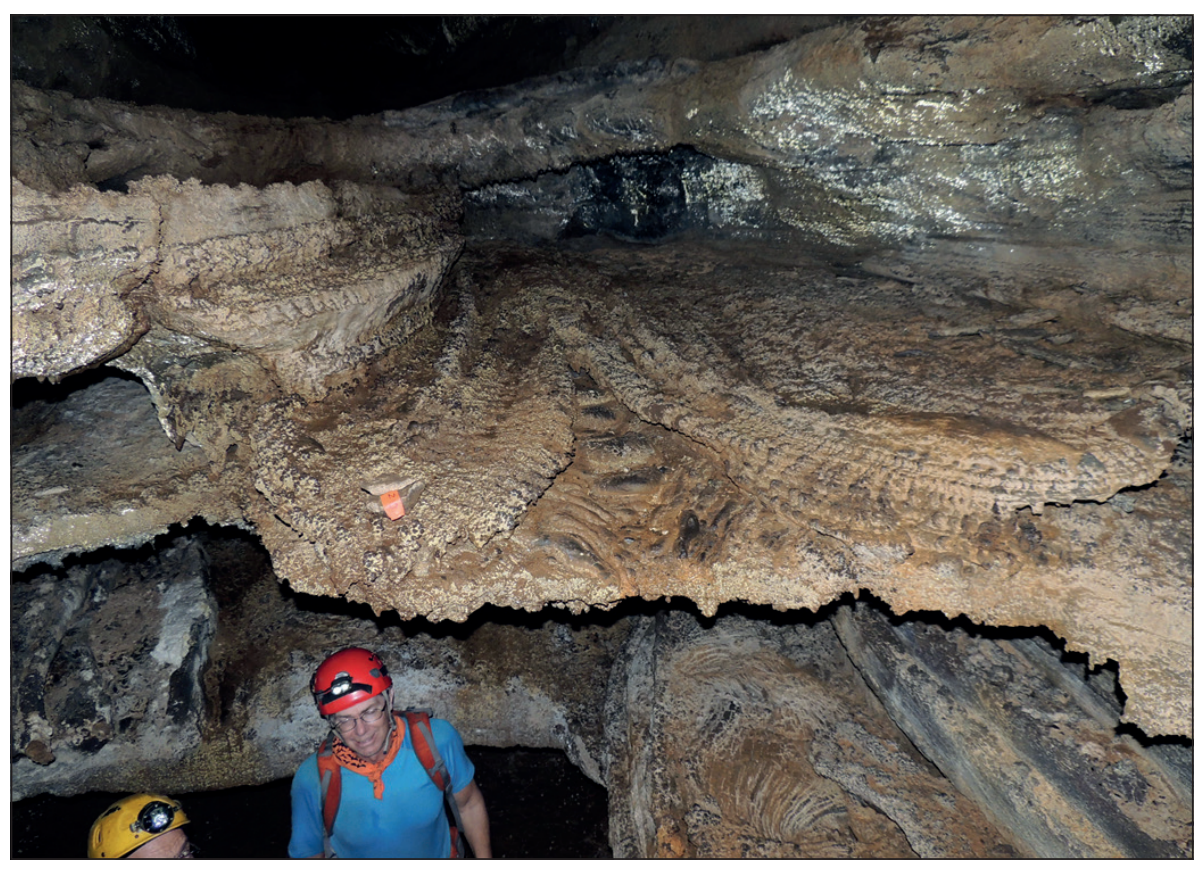

Fig. 12: "The Zipper", illustrating the closure of a secondary ceiling by inward and downslope growth of small shelves (Photo: S. Kempe). 
apron and collapsed because there the passage is up to 8 $\mathrm{m}$ wide. From the amount of rocks collapsed it remains unclear whether Puka 2 had already a small opening during activity (i.e., if it was a "hot puka") or if it collapsed after the termination of the activity (a "cold puka"). This discussion is essential, because the source of the cold air causing the solidification of the secondary ceiling needs to be determined. Beyond, the passage continues until breakdown is encountered. To the left another apron is covered with blocks from the ceiling. Here the primary roof did not entirely collapse because it seems to consist of several pāhoehoe layers, just as in normal inflationary roofs. Between the breakdown blocks, $40 \mathrm{~m}$ below Puka 2, at station Z13, a small hole leads into the lower passage. From here another $30 \mathrm{~m}$ of passage with only a few blocks leads to station Z15 at the brink of Puka 3. The puka, actually a double skylight, is again off-center, on this particular occasion to the left of the passage. The collapse of the puka has also punctured the floor, i.e., the upper secondary ceiling, so that one is able to look down

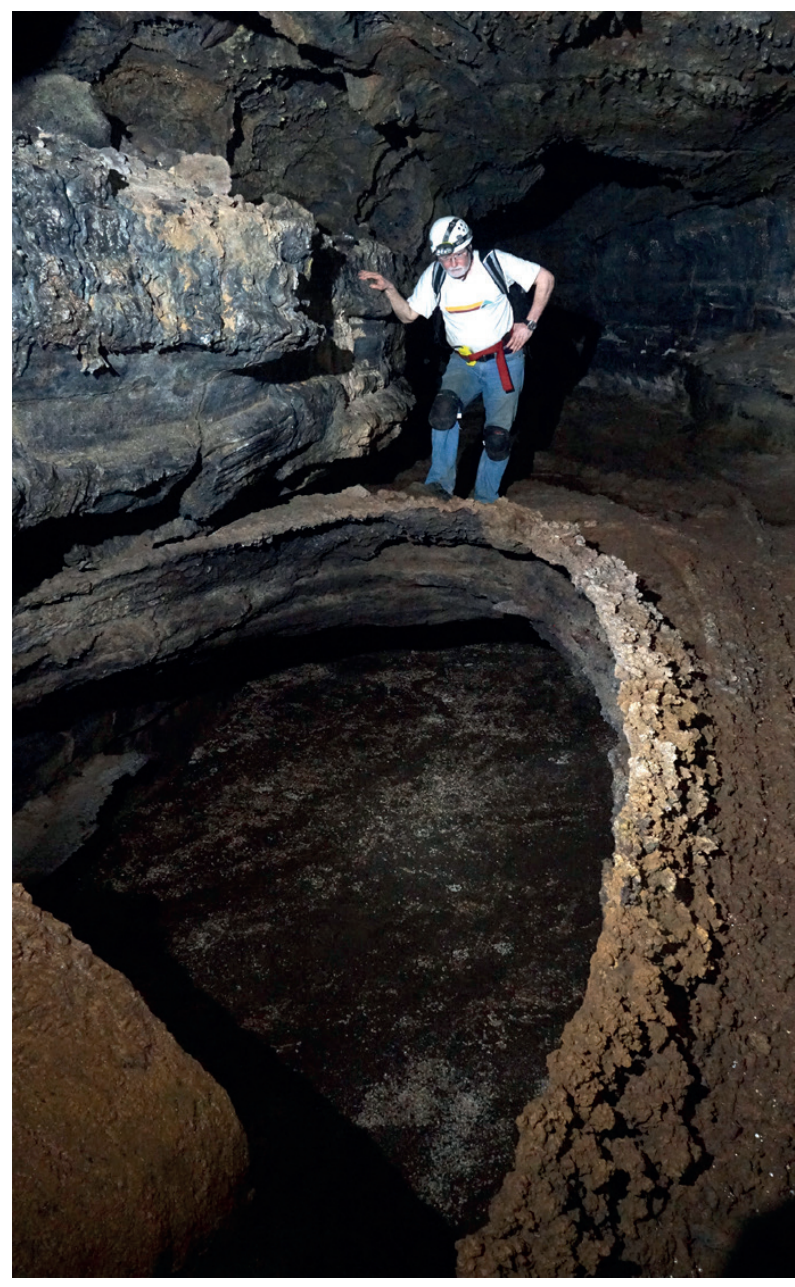

Fig. 13: Levee at station Z6 on top of the lowest secondary ceiling looking downhill (Photo: G. Middleton). into the lower passage. The collapse of the primary roof and that of the secondary ceiling has produced a sizable pile of blocks (at station Y12); thus, both collapses seem to be "cold". Beyond the puka the upper passage is lower and blocked by breakdown. At this place the secondary ceiling appears to be at least a meter thick.

Back at station Z13 and to the hole in the floor, one is able to climb easily down to the lower passage (see passage cross-section st. Z13, Fig. 11). There the secondary ceiling appears to be less thick. In fact this hole most probably has not been caused by breakdown but is a spill hole or a gas-escape hole. This would explain why a set of secondary ceilings extends downslope from there. It seems that they solidified because colder air leaked down from the upper passage. These secondary ceilings are of variable lengths and allow one to climb down to the lowermost septum as on a flight of steps (see longitudinal section, Fig. 11). The lowermost secondary ceiling (level 6 if counted from above) ends downhill $6 \mathrm{~m}$ upslope of station Y12. It has a total length of $54 \mathrm{~m}$ to be added to

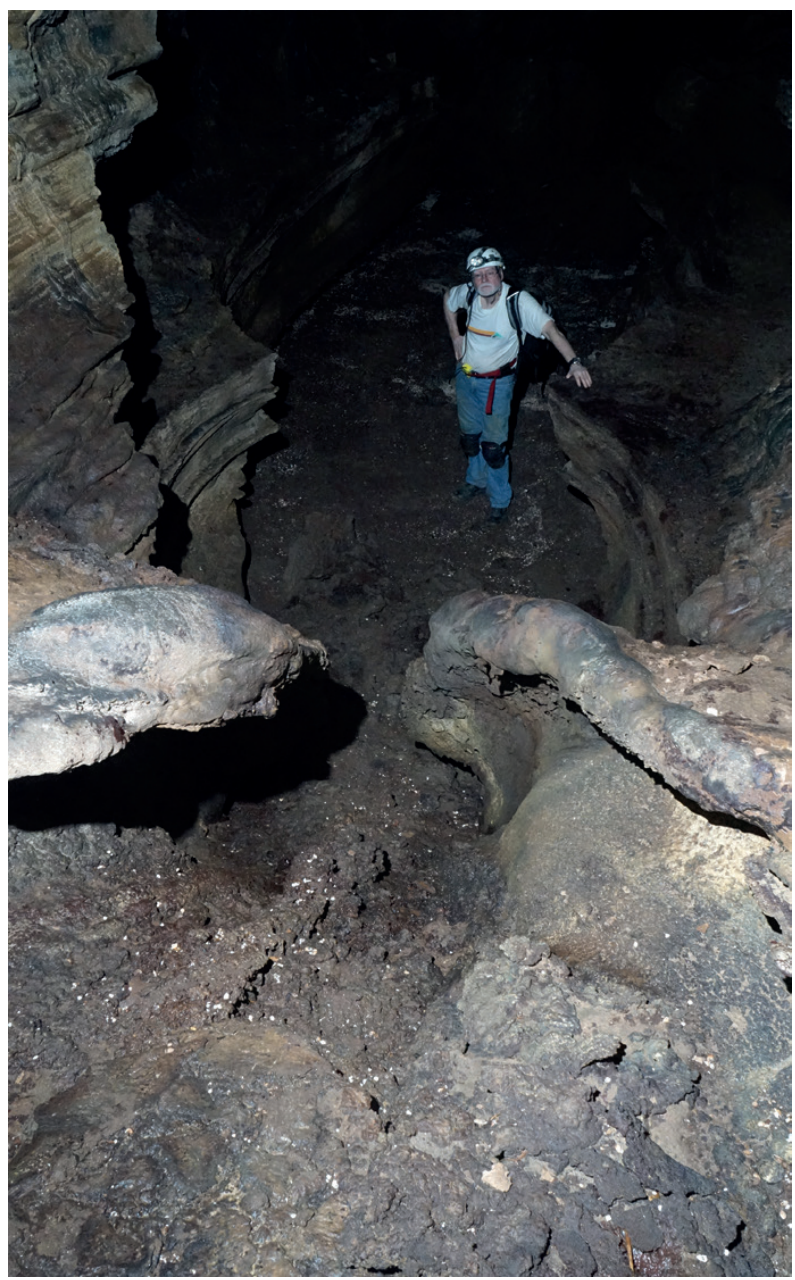

Fig. 14: Lavafall and shelf-oval between stations Z4 and Z5, looking downhill (Photo: G. Middleton). 


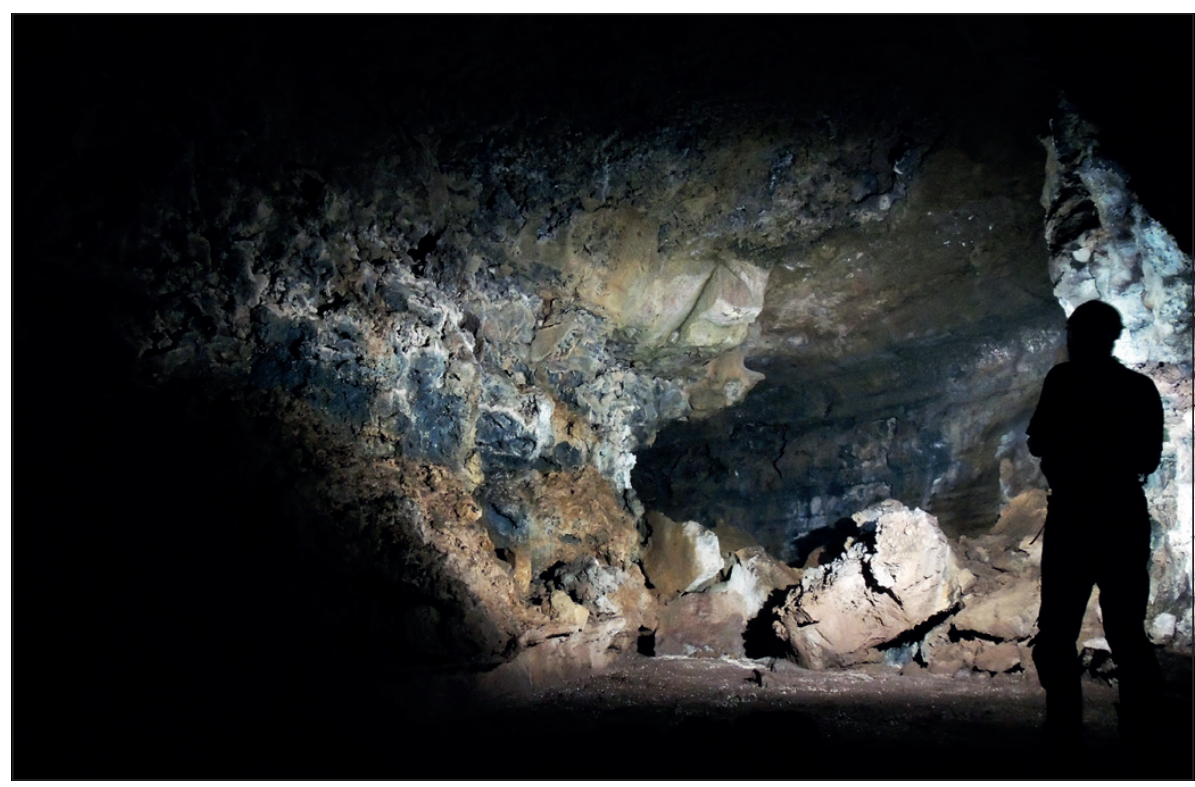

Fig. 15: View of the south wall below station $\mathrm{Z} 2$. To the right remains of the lining can be seen while to the left the eroded-into rocks are exposed, a series of pāhoehoe sheets covered by 'a'à rubble (Photo: $S$. Kempe).

the cave's length. The intermediate levels are of various lengths, the longest one measures $35 \mathrm{~m}$, extending from station Z5a to Z12 (level 2 from above). The remaining three levels are only about $5 \mathrm{~m}$ long and leave only small openings in between them (see longitudinal section, Fig. 11). At station $Z 10$ there is a collapse hole in the lowest secondary ceiling and above it the next higher septum ends zipper-like (Fig. 12).

Below the lowest secondary ceiling the cave passage has a width of $4 \mathrm{~m}$ and a height of $1.2 \mathrm{~m}$. The final lava flow in the cave therefore had a cross-sectional area of $5 \mathrm{~m}^{2}$. This passage gives access to the upper part of the lower cave at station Z6. There the secondary ceiling ends but continues in the form of shelves for $20 \mathrm{~m}$. At Z6 a low levee at the beginning of the secondary ceiling is evident (Fig. 13). It is remarkable since it shows that no lava balls stranded on top of the secondary ceiling. Furthermore, no spattering is evident, suggesting that the lava was essentially degassed. These observations reveal much regarding the properties of the lava in the cave.

Upward of station Z5 the shelves swing around in a regular oval, preserving the pattern of the turbulence of the terminal flow in the cave. Then the shelves almost join and curve upward, forming convex shells hovering above a lavafall (Fig. 14). Above, the shelves can be followed for some distance on the walls, marking the level of the terminal flow (station $\mathrm{Z} 4$ is on this shelf).

The cave widens upslope of station Z4 to the largest and probably most complex room in this section. In contrast to the passages visited before, here most of the lining has collapsed during activity and has been carried away. This allows a view of the country rock behind the lining (Figs. 15, 16). On the walls on both sides a series of pāhoehoe sheets are exposed (Fig. 15) followed by a thick irregular layer of 'a'ā rubble and a thick 'a'à core near the ceiling (Fig. 16 upper left). The unusually large blocks on the floor of the passage derive from this 'a'a core. Above

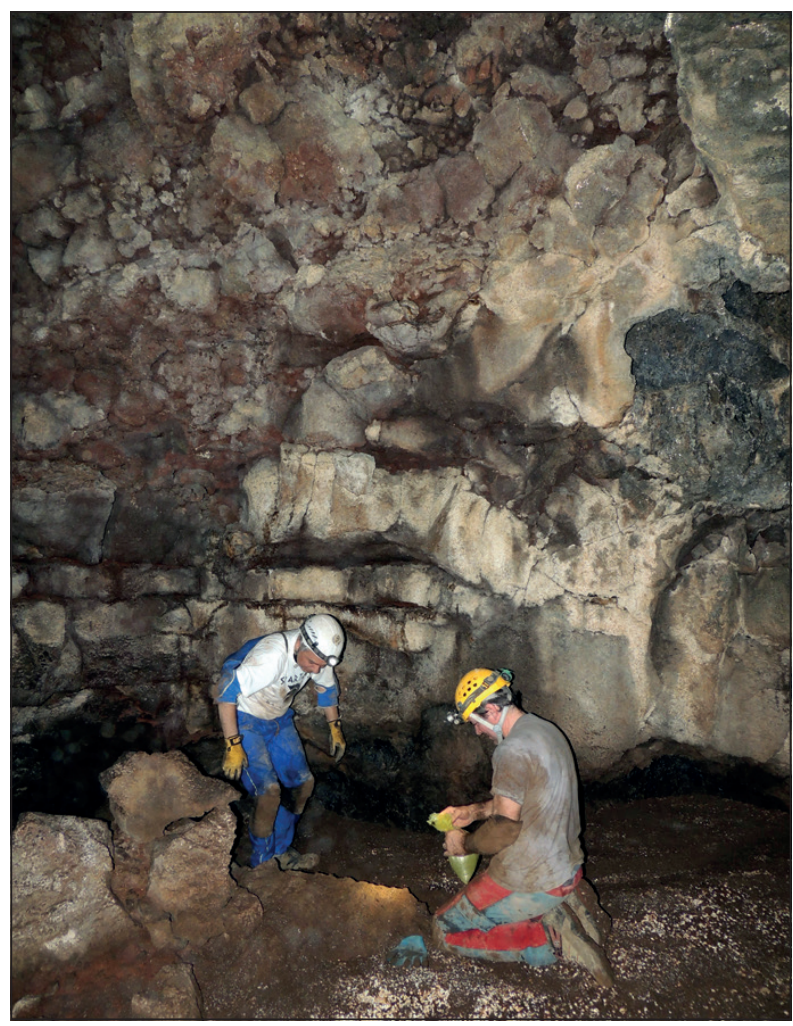

Fig. 16: View downhill towards station Z3 (on the big block in center). At the ceiling the core of an 'a'a flow is exposed that also is responsible for the big breakdown blocks on the floor. The ceiling to the left is formed by 'a' $a$ rubble while to the right the uppermost secondary ceiling is seen, forming the floor of the upper passage (Photo: S. Kempe) 
the 'a' $\mathrm{a}$ core, the ceiling is formed by the top-rubble of this 'á $\mathrm{a}$ flow. It is the identical rubble that is exposed in the wall of the upper passage at station Z20 where the hole connects down to the lower passage.

Beyond this hall-like widening, the passage resumes the form of a narrow canyon with intact lining. The passage is filled with a breakdown pile, the origin of which is uncertain, because at the top of the pile, the uppermost secondary ceiling is reached that has only a relatively small hole filled with blocks. Daylight is not visible, even though this point is beyond the opening of Puka 1 in the upper passage. To the left of the blocks, we opened a low crawlway. This leads into a small room behind the breakdown that ends in a miniature lavafall, sealing the backside. On the floor another secondary ceiling is evident and after a few blocks of breakdown were removed, a second crawl was entered that lead to a narrow, about 5 $\mathrm{m}$-high shaft. It was not possible to climb to its top due to the presence of fragile rock. The survey suggests that it is to the south of the trench at Puka 1. Its genesis is difficult to understand and will unfortunately remain an enigma for the time being. The floor of the shaft, as well as the crawl and the entire area at the foot of the breakdown in the big hall down to station $\mathrm{Z} 4$ is covered with reddish sediment as in a delta, interspersed with large quantities of shells from land snails (compare Fig. 15). Small stream beds indicate that the sediment is washed in from the trench at Puka 1 during flash floods.
Notwithstanding small errors in the survey, it is possible to calculate the slope of the pyroduct. This is best done for the upper passage since the slope of the lower passage is modified by erosion. Between stations Z22 and Z15 the sum of horizontal survey lines amounts to 136.5 $\mathrm{m}$ and the vertical distance is $8.2 \mathrm{~m}$. This yields a slope of $3.44^{\circ}$. Better yet is the slope of the ceiling. As Z22 is 0.5 $\mathrm{m}$ and Z15 $1.3 \mathrm{~m}$ below the ceiling, the vertical distance is reduced to $7.5 \mathrm{~m}$, yielding a slope of $3.1^{\circ}$. In contrast to this the floor, i.e. the upper secondary ceiling, has a vertical distance of $7.2 \mathrm{~m}$ (Z22 $2.2 \mathrm{~m}$ above floor; Z15 $1.2 \mathrm{~m}$ above floor) yielding a slope of $3.0^{\circ}$. Such a slope is quite typical for pyroducts (compare Kempe 2019). When looking at the longitudinal section, it is evident that the slope is less in the downslope and higher towards the upslope end of the surveyed section.

The total depth of the cave is quite variable. At station $\mathrm{Z} 3$ the lower passage is $5.8 \mathrm{~m}$ and the upper passage $3.6 \mathrm{~m}$ high (Z20). With an estimated thickness of $0.5 \mathrm{~m}$ of the upper secondary ceiling, the total depth of the pyroduct thus amounts to $10.1 \mathrm{~m}$. At Z13 the depth is $11 \mathrm{~m}$ and at $\mathrm{Y} 12,8 \mathrm{~m}$ (measured always below the primary roof). At the commonly used entrance (Puka 5 in our count) the depth is only $5.2 \mathrm{~m}$. These data indicate that the depth of erosion is quite variable (differences of a factor of two). The depth of the few small side-passages is a meter (at st. Z19 but also at the ceiling below Puka 5), suggesting that the lava eroded up to $10 \mathrm{~m}$ down.

\section{CASE STUDY CUEVA DEL GALLARDO}

The lava forming Cueva del Gallardo flowed from the upper exit in the tourist section (TS) south-south-west. The flow was mostly confined to just one conduit. Only two (one short, one longer) oxbows (cut-arounds) are encountered in the non-tourist section (NTS). There the original lava flow split, possibly flowing around an obstacle. The conduit that had the larger flow-rate cut down and drained the other, higher conduit. The level of these higher conduits marks the level of the initial lava level when the flow crept across the surface.

This initial sheet of lava, the primary roof, is best observed just below the lowest skylight in the NTS (Fig. 5). The primary roof is composed of a more than $1 \mathrm{~m}$ thick lava sheet that stretches without much change in thickness across the passage. It is only structured by vertical contraction cracks and horizontal vesicle accumulations, some of which led to a split in the rock causing a sort of layering within the lava sheet. Whether this sheet has a ropy surface structure is not clear because we were able to observe it only in cross-section, but it certainly is a sheet of pāhoehoe. On top of this sheet lies an irregular, welded 'a'a rubble layer. Above that lies the thick core ("blue rock") of the interior of the 'a'a flow. The 'a'a core partly also collapsed forming the unusually large and angular blocks along and below which, , one has to crawl. This 'a'a- -unit was emplaced on the roof of the cave after it formed. It could have derived from the same eruption that fed the pyroduct or from a later eruption. In any case, it loaded the roof with much additional weight, causing its post-activity collapse, exposing the primary roof and the two layers of the 'a'a flow. The existence of one primary roof sheet excludes the possibility that the cave formed by the crusting over of an open lava channel. Thus, the cave belongs to the "inflationary" pyroducts, i.e., the cave roof formed first and the lava kept flowing underneath invisible to any surface observer (had there been one).

The entrance to both the upper TS and the low- 
er NTS section is through another collapse (entrance puka). The structure of the roof exposed above both of the cave entrances has a more complex interpretation as it is composed of several, irregularly thick and bent sheets of lava. These lava sheets are well above the primary pāhoehoe sheet that should be much lower than what now forms the cave roof. These layers therefore were emplaced later onto the roof, just as the 'a'a flow discussed above. However, these flows must have been emplaced while the pyroduct was still active because, when observed from underneath, they are seen to have been thermally eroded, forming small cupolas. Appar- ently, the initial primary sheet of the roof was removed partially (by breakdown) and then an inundation event (initiated by a constriction or collapse further down the pyroduct) caused the lava to rise to the ceiling, leaving a prominent accreted layer seen on the ceiling. Shortly after, melting of the interior of the blocks between the contraction cracks commenced. The material adjacent to the contraction cracks was already cooled and is preserved as ridges along both sides of the contraction crack. Thus the ceiling has the appearance of large, irregular honeycombs (Fig. 17). This ceiling texture is observed in the hall uphill of the puka collapse and

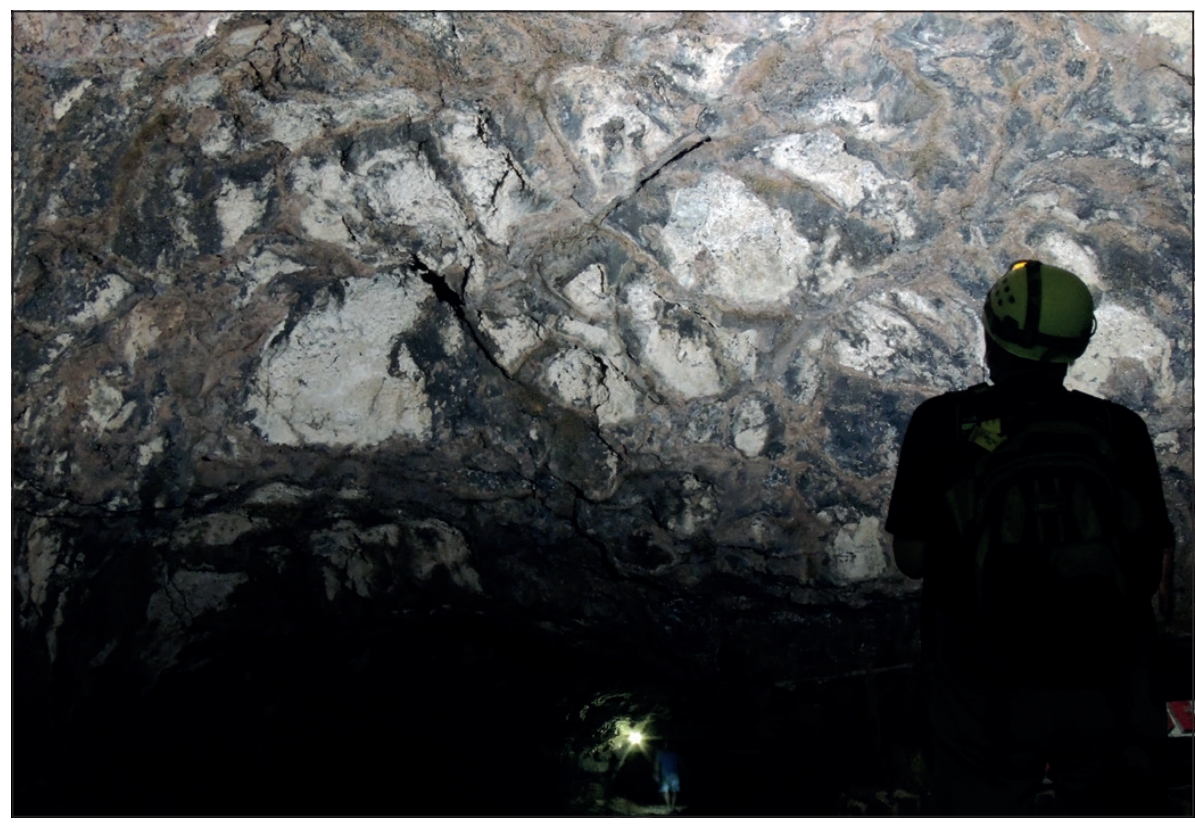

Fig. 17: View towards the ceiling in Cueva del Gallardo upslope of entrance puka (tourist section). Its pattern reminds one of a honeycomb. The interior of the blocks seem to be thermally eroded, while the material adjacent to the contraction cracks remains as pronounced ridges (Photo: S. Kempe).

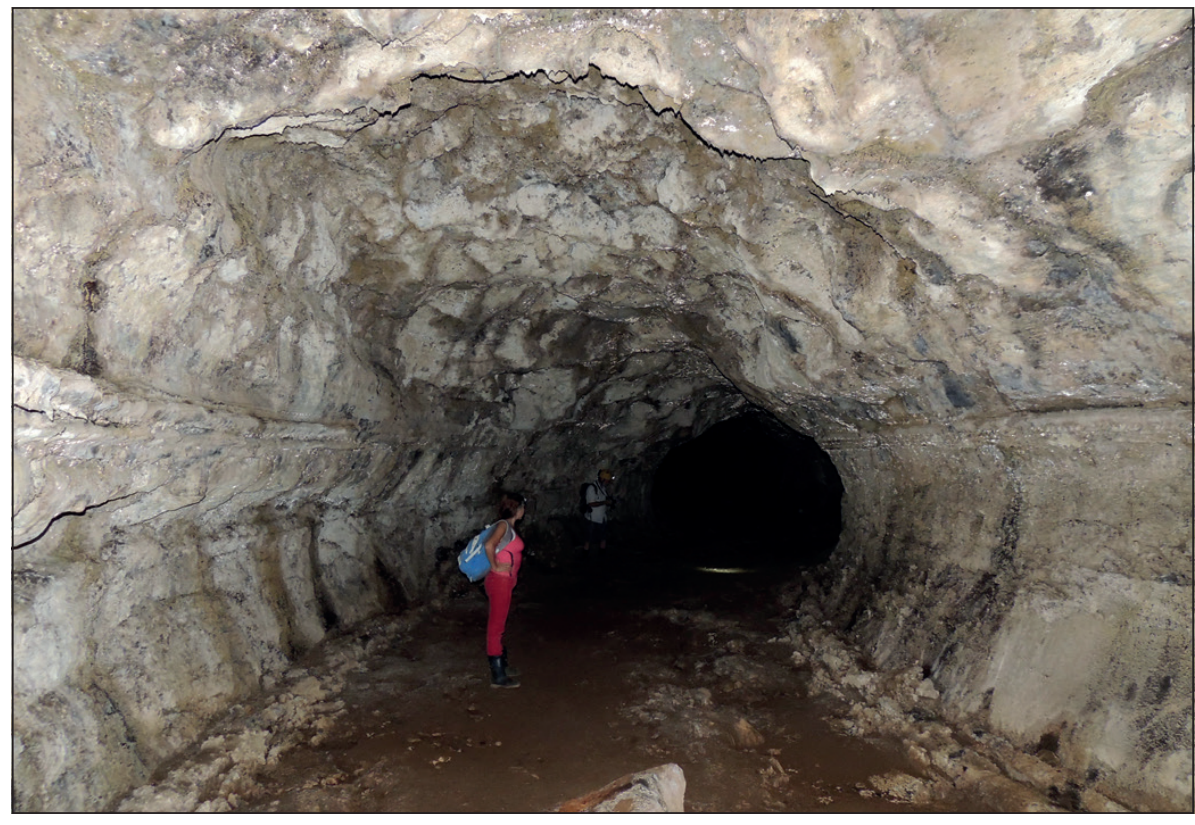

Fig. 18: View into Cueva del Gallardo below the entrance puka (nontourist section). Here also the roof shows a honeycomb pattern with the interior of the blocks thermally eroded and the contraction cracks forming ridges (Photo: S. Kempe). 


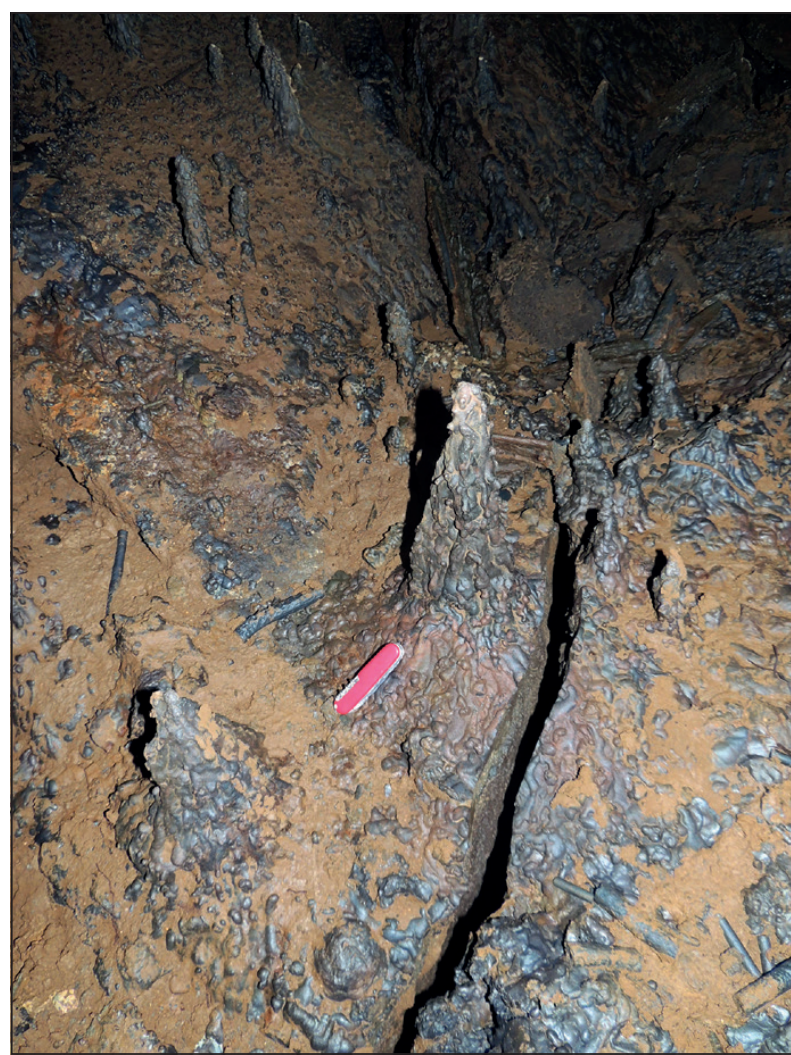

Fig. 19: At the terminus of the Cueva del Gallardo the lava seems to have ponded, providing heat for an extended time period. Thus, deep contraction cracks in the floor developed and residual melt was extruded from the ceiling, forming lava stalactites and stalagmites (Photo: S. Kempe).

some way into the continuing passage as well as in the preserved ceiling below the collapse and also into the downward continuing passage (Fig. 18). Because of the hot breakdown, that formed a hall-like widening, more lava and greater heat was available in this section of the cave causing these unusual cupolas. Once the constriction was removed and the lava began flowing again, the level of the lava receded to the height of the tunnel leading off, causing a shelf to freeze out within the former hall. Much later the entire roof collapsed, forming the present entrances.

During the activity of the pyroduct it apparently did not have any collapses open to the surface, because otherwise the hot gases would have escaped and internal, secondary ceilings (septa) would have formed, such as seen in Cueva del Cascajo. The total flow through the cave is difficult to judge, but it might have been substantial. Nevertheless, this substantial flow (judging from the relative stable area of the cross-section in the NTS) may have been short-lived, because the downward erosion below the level of the small oxbow was in the order of $1.5 \mathrm{~m}$. Shelves are also not prominent (because of the lack of gas-escape) but do exist in a few places also giving witness to a moderate downward erosion. The lining of the cave is well preserved and only in a few places is one able to observe that older layers, such as 'a'ā rubble, were eroded into.

Not many lavafalls occur in the cave. The highest, albeit not vertical, is found right at the upper entrance (exit) of the TS. Several smaller falls, all less than a meter in height, are found in the NTS. This again implies that downward erosion was not a prominent process within this pyroduct.

Most remarkable is the terminus of the cave: it is a lava sump, i.e. lava ponded above a constriction. Thus the passage becomes low, but at the same time the heat in the ponded lava was preserved for a long time. This enabled residual melt to be extruded from the ceiling and walls, forming a rich population of drip-generated stalagmites, up to one meter long and final extrusion of stalactites up to one meter long (Kempe 2013). That the ponding lava had a considerable depth is demonstrated by the deep contraction cracks in the floor that are not seen elsewhere in the cave (Fig. 19).

\section{CONCLUSIONS}

The genesis of the visited caves on Galápagos can be explained by the pyroduct models developed by studying lava caves on Hawai'i. Of the four models suggested so far, the caves on Galápagos seem to fit the "inflation model" (Fig. 2), i.e., the caves developed below a primary roof of pāhoehoe. However, in Galápagos the primary roof seems to consist of only one sheet, while in Hawai' $i$ most inflationary cave roofs seem to consist of several sheets. This single sheet may nevertheless be quite thick and may be separated by internal shear zones, marked by horizontal layers of vesicles.

In a subgroup of the visited caves, the primary roof consists of additional flows of the same eruption on top of the primary pāhoehoe sheet. These roofs are several meters thick. In the course of activity both the primary pāhoehoe sheet and part of the overlaying lava can collapse and be consumed in the flow. In this way relatively 
irregular internal ceiling structures may arise (Chato I, Gallardo, Royal Palm).

The most prominent process enlarging the Galápagos pyroducts is downward erosion. Evidence of this process has been observed in all but two of the caves in the form of exposed older 'a'ā flows and even an older paleosol (Premisias, compare Fig. 7). This downward erosion can amount to as much as (in Cascajo) $10 \mathrm{~m}$.

In order to characterize the various pyroducts, we are able to review common features and correlate them to the developmental stage of a given pyroduct. These features include oxbows, relative amounts of downcutting, lavafalls or other erosive features, pukas and secondary ceilings, as well as evidence of any process resulting in further structural modification. More advanced development of a pyroduct is correlated with a greater presence and total number of these features. By a correlation of these features we are able to define three stages of development:

Stage 1, juvenile pyroducts exhibiting embryonic braided or single conduits with no evidence of secondary ceilings, erosion or lavafalls,

Stage 2, a well-developed adult stage having some consolidation of channels and channel erosion and possibly including oxbows, one or few secondary ceilings, or other features but lacking signifi- cant morphological modifications from them; and, finally,

Stage 3, fully mature with well-developed channels representing significant downward erosion, with a partial loss of the primary roof, often multiple secondary ceilings and other evidence of significant structural evolution.

We consider that the correlation of features in this way between pyroducts in various contexts may assist in furthering the understanding of the processes that form them. Using these criteria we have assigned relative maturity levels (Tab. 1) to the individual caves with the Túnel del Estero being the least developed (exhibiting no downcutting with no specific internal differentiation) and the Cueva del Cascajo as the most developed (exhibiting the largest amount of downcutting, multiple internal roofs, extensive structural modification.)

Undoubtedly, further work is needed to establish uniform principles to help us understand and describe the formation of pyroducts in the Galápagos and elsewhere. Certainly, only further detailed observation and mapping of pyroducts will be able to advance our understanding of the genesis and development of lava flows and thus better explain basalt-based volcano behavior during eruptive activity.

\section{ACKNOWLEDGEMENTS}

The authors are indebted to the owners of the caves visited that allowed access to their property and caves. We are also grateful to the Galápagos National Park for hosting the symposium and for the company of their rangers in the field. We are grateful to La Sociedad Espeleológica Científica Ecuatoriana (ECUCAVE) for their support and assistance. We also have to thank the participants of the $16^{\text {th }}$ International Symposium on Vulcanospeleology for their patience during exciting discussions about the genesis and the development of pyroducts in the field. The suggestions of a reviewer helped to improve the paper.

\section{REFERENCES}

Addison, A., 2011: Galápagos, caving the equator.- National Speleological Society News, 69, 6, 8-17.

Allred, K. \& C. Allred, 1997: Development and morphology of Kazumura Cave, Hawai'i.- Journal of Cave and Karst Studies, 59, 2, 67-80.

Amelung, F., Jónsson, S., Zebker, H. \& P. Segall, 2000: Widespread uplift and trapdoor faulting on Galápagos volcanoes observed with radar interferometry.Nature, 407, 993-996.
Bauer, I., 2011: Geologie, Petrographie und Pyroductgenese des Kahuku-Ranch-Gebiets Big Island, Hawai'i.Diploma Thesis, Institute of Applied Geosciences, Technical University Darmstadt, Germany, pp. 167 (unpublished).

Bauer, I., Kempe, S. \& P. Bosted, 2013: Kahuenaha Nui (Hawai'i): A cave developed in four different lava flows.- In: Filippi, M. \& P. Bosák, P. (eds.), Proceedings $16^{\text {th }}$ International Congress of Speleology, $21^{\text {st }}$. 
$28^{\text {th }}$ July 2013, Brno. Czech Speleological Society, 231-236, Praha.

Bow, C.S., 1979: The Geology and Petrogenesis of the Lavas of Floreana and Santa Cruz Islands, Galápagos Archipelago.- Ph.D. thesis, Eugene, University of Oregon, pp. 308, Oregon.

Bunnell, D., 2013: Caves of Fire 2 - Inside America's Lava Tubes.- National Speleological Society, pp. 144, Huntsville, Alabama.

Calvari, S. \& H. Pinkerton, 1998: Formation of lava tubes and extensive flow field during the 1991-1993 eruption of Mount Etna.- Journal of Geophysical Research: Solid Earth, 103, B11, 27291-27301. https:// doi.org/10.1029/97JB03388

Calvari, S. \& H. Pinkerton, 1999: Lava tube morphology on Etna and evidence for lava flow emplacement mechanisms.- Journal of Volcanology and Geothermal Research, 90, 3-4, 263-280. https://doi. org/10.1016/S0377-0273(99)00024-4

Constantin, S., Toulkeridis, T. Moldavan, O.T., Villacis, M. \& A. Addison, 2018: Caves and karst in Ecuador - state of-the-art and research perspectives.- Physical Geography, 40, 1, 28-51. https://doi.org/10.1080 /02723646.2018.1461496

Chadwick, W.W. \& K.A. Howard, 1991: The pattern of circumferential and radial eruptive fissures on the volcanoes of Fernandina and Isabela islands, Galápagos.- Bulletin of Volcanology, 53, 4, 259-275. https://doi.org/10.1007/BF00414523

Coan, T., 1844: Letter of March 15, 1843 describing the Mauna Loa eruption of 1843.- Missionary Herald, 1844.

Darwin, C.R., 1859: The Origin of Species.- Murray, pp. 502, London.

Geist, D.J., Harpp, K.S., Naumann, T.R., Poland, M., Chadwick, W.W., Hall, M. \& E. Rader, 2008: The 2005 eruption of Sierra Negra Volcano, Galápagos, Ecuador.- Bulletin of Volcanology, 70, 6, 655-673. https://doi.org/10.1007/s00445-007-0160-3

Greeley, R., Fagents, S.A., Harris, R.S., Kadel, S.D. \& D.A. Williams, 1998: Erosion by flowing lava, field evidence.- Journal of Geophysical Research, 103, B11, 27325-27345. https://doi. org/10.1029/97JB03543

Hall, M.L., 1983: Origin of Española Island and the age of terrestrial life on the Galápagos Islands.- Science, 2, 21, 545-547.

Harpp, K.S. \& W.M. White, 2001: Tracing a mantle plume: Isotopic and trace element variations of Galápagos seamounts.- Geochemistry, Geophysics, Geosystems, 2. https://doi.org/10.1029/2000GC000137

Harpp, K.S. \& D.J. Geist, 2002: Wolf-Darwin lineament and plume-ridge interaction in northern Galápa- gos.- Geochemistry, Geophysics, Geosystems, 3, 8504. https://doi.org/10.1029/2002GC000370

Harpp, K.S., Wanless, V.D., Otto, R.H., Hoernle, K.A. \& R. Werner, 2003: The Cocos and Carnegie aseismic ridges: A trace element record of long-term plumespreading center interaction.- Journal of Petrology, 46, 1, 109-133. https://doi.org/ 10.1093/petrology/ egh064

Heliker, C., Swanson, D.A. \& T.J. Takahashi (eds.), 2003: The Pu'u 'Ō'ó-Küpaianaha Eruption of Killauea Volcano, Hawai $i$ : The First 20 Years.- US Geological Survey Professional Papers, 1676, pp. 206.

Helz, R.T., Heliker, C., Hon, K. \& M. Mangan, 2003: Thermal efficiency of lava tubes in the Pu'u 'Ō'ōKūpaianaha eruption.- US Geological Survey Professional Paper, 1676, 105-120.

Hernández, J.J., Izquierdo, I. \& P. Oromí, 1992: Contribution to the vulcanospeleology of the Galápagos Islands.- In: Rea, T. (ed.) Proceedings $6^{\text {th }}$ International Symposium on Vulcanospeleology, August 1991, Hilo. National Speleological Society, 204-220, Huntsville, Alabama.

Hey, R., 1977: Tectonic evolution of the Cocos-Nazca spreading center.- Geological Society of America Bulletin, 88, 1404-1420.

Hoernle, K., van den Bogaard, P., Werner, R., Hauff, F., Lissinna, B., Alvarado, G.E. \& D. Garbe-Schönberg, 2002: Missing history (16-71 Ma) of the Galápagos hotspot: implications for the tectonic and biological evolution of the Americas.- Geology, 30, 9, 795-798. https://doi.org/10.1130/00917613(2002)030<0795:MHMOTG>2.0.CO;2

Holden, J.C. \& R.S. Dietz, 1972: Galápagos Gore, NazCoPac Triple Junction and Carnegie/Cocos Ridges.Nature, 100, 266-269.

Hon, K., Kauahikaua, J., Denlinger, R. \& K. Mackay, 1994: Emplacement and inflation of pāhoehoe sheet flows: Observations and measurements of active lava flows on Kilauea Volcano, Hawai'i.- Geological Society of America Bulletin, 106, 351-370.

Jordá-Bordehore, L. \& T. Toulkeridis, 2016: Stability assessment of volcanic natural caves - lava tunnels - using both empirical and numerical approach, case studies of Galápagos Islands (Ecuador) and Lanzarote Island (Canary - Spain).- In: Ulusay, R., Aydan, O., Gerçek, H., Hindistan, M.A. \& E. Tuncay (eds.) Rock Mechanics and Rock Engineering: From the Past to the Future, International Symposium on International Society for Rock Mechanics, ISRM 2016, 29 $9^{\text {th }}-31^{\text {st }}$ August 2016, Ürgüp, Cappadocia Region, Turkey. CRC-Press, 2: 835-840, London.

Jordá-Bordehore, L., Toulkeridis, T., Romero-Crespo, P.L., Jordá-Bordehore, R. \& I. García- Gariazabal, 
2016: Stability assessment of volcanic lava tubes in the Galápagos using engineering rock mass classifications and by empirical approach.- International Journal of Rock Mechanics \& Mining Sciences, 89, 55-67. https://doi.org/10.1016/j.ijrmms.2016.08.005

Kauahikaua, J., Sherrod, D.R., Crashman, K.V., Heliker, C., Hon, K., Mattox, T.N. \& J.A. Johnson, 2003: Hawaiian lava-flow dynamics during the Pu'u 'O'ōKūpaianaha eruption: A tale of two decades.- US Geological Survey Professional Paper, 1676, 63-87.

Kempe, S., 1997: Lavafalls, a major factor for the enlargement of lava tubes of the Ai-la'au Shield phase, Kìlauea, Hawai' i.- In: Jeannin, P.Y. (ed.) Proceedings of the $12^{\text {th }}$ International Congress of Speleology, $10^{\text {th }}$ $17^{\text {th }}$ August 1997, La Chaux de-Fonds, Switzerland. Swiss Speleological Society, 1, 445-448, La Chaux de-Fonds.

Kempe, S., 2002: Lavaröhren (Pyroducts) auf Hawai'i und ihre Genese.- In: Rosendahl, W. \& A. Hoppe (eds.) Angewandte Geowissenschaften in Darmstadt. Schriftenreihe der deutschen Geologischen Gesellschaft, 15, Deutsche Geologische Gesellschaft, pp. 109-127, Hannover.

Kempe, S., 2012: Lava caves, types and development.In: Al-Malabeh, A. (ed.) Hashemite University Abstracts and Proceedings $15^{\text {th }}$ International Symposium on Vulcanospeleology, $15^{\text {th }}-22^{\text {nd }}$ March 2012, Zarka, Jordan. Hashemite University, 49-56, Zarka, Jordan.

Kempe, S., 2013: Morphology of speleothems in primary (lava-) and secondary caves.- In: Shroder, J. \& Frumkin, A. (eds.) Treatise on Geomorphology. Academic Press, vol. 6, Karst Geomorphology, pp. 267-285, San Diego.

Kempe, S., 2019: Volcanic rock caves, Encyclopedia of Caves (Third Edition).- Academic Press/Elsevier, pp. 118-1127, Amsterdam.

Kempe, S. \& C. Ketz-Kempe, 1992a: Lava tube systems of the Hilina Pali area, Ka'u District, Hawaii.- In: Rea, T. (ed.) Proceedings $6^{\text {th }}$ International Symposium on Vulcanospeleology, August 1991, Hilo. National Speleological Society, 15-25, Huntsville, Alabama.

Kempe, S. \& C. Ketz-Kempe, 1992b: Underground observations during the Pu'u O'o earthquake, 4.06 p.m., Aug. 8, 1990.- In: Rea, T. (ed.) Proceedings $6^{\text {th }}$ International Symposium on Vulcanospeleology, August 1991, Hilo. National Speleological Society, 2934, Huntsville, Alabama.

Kempe, S., Bauer, I., Bosted, P. \& S. Smith, 2010: Whitney's Cave, an old Mauna Loa/Hawaiian pyroduct below Pahala ash: An example of upward-enlargement by hot breakdown.- In: Middleton, G.J. (ed.) Proceedings $14^{\text {th }}$ International Symposium on Vulcanospeleology, $12^{\text {th }}-17^{\text {th }}$ August 2010, Undara, Aus- tralia. Organising Group, for International Union of Speleology Commission on Volcanic Caves, 103113, Sandy Bay, Tasmania, Australia.

Kempe, S., Al-Malabeh, A. \& H.V. Henschel, 2012: Jordanian lava caves, an overview.- In: Al-Malabeh, A. (ed.) Hashemite University Abstracts and Proceedings $15^{\text {th }}$ International Symposium on Vulcanospeleology, $15^{\text {th }}-22^{\text {nd }}$ March 2012, Zarka, Jordan. Hashemite University, 38-42, Zarka, Jordan.

Kurz, M.D. \& D. Geist, 1999: Dynamics of the Galápagos hotspot from helium isotope geochemistry.- Geochimica et Cosmochimica Acta, 63, 4139-4156.

Lockwood, J.P. \& R.W. Hazlett, 2010: Volcanoes, a Global Perspective.- John Wiley/Blackwell, pp. 624, Chichester.

McBirney, A.R. \& H. Williams, 1969: Geology and Petrology of the Galápagos Island.- Geological Society of America Memoirs, 118, pp. 197

Middleton, G. \& S. Kempe, 2021: North Queensland lava caves. - In: Webb, J. (ed.) Caves of Australia, Springer, in press.

Rea, G.T. (ed.), 1992: Proceedings $6^{\text {th }}$ International Symposium on Vulcanospeleology, August 1991, Hilo, Hawaii. National Speleological Society, pp. 286, Huntsville.

Reynaud, C., Jaillard, E., Lapierre, H., Mamberti, M. \& G.H. Mascle, 1999: Oceanic plateau and island arcs of southwestern Ecuador: Their place in the geodynamic evolution of northwestern South America.Tectonophysics, 307, 235-254.

Reynolds, R., Geist, D.J. \& M.D. Kurz, 1995: Physical volcanology and structural development of Sierra Negra, Isabela Island, Galápagos Archipelago.Geological Society of America Bulletin, 107, 13981410.

Sauro, F., Pozzobon, R., Santagata, T., Tomasi, I., Tonello, M., Martínez-Frías, J., Smets, L.M.J., Gómez, G.D.S. \& M. Massironi, 2019: Volcanic Caves of Lanzarote: A Natural Laboratory for Understanding VolcanoSpeleogenetic Processes and Planetary Caves.- In: Mateo, E., Martínez-Frías, J. \& J. Vegas (eds.) Lanzarote and Chinijo Islands Geopark.- From Earth to Space, Springer, pp. 125-142, Heidelberg.

Sauro, F., Pozzobon, R., Massironi, M., Bernardisi, P. de, Santagata, T. \& J. de Waele, 2020: Lava tubes on Earth, Moon and Mars: a review on their size and morphology revealted -by comparative planetology.- Earth-Science Reviews, 209, 103288, https:// doi.org/10.1016/j.earscirev.2020.103288.

Sigurdsson, H., Houghton, B.F., McNutt, S.R., Rymer, H. \& J. Stix (eds.), 2000: Encyclopedia of Volcanoes.Academic Press, pp. 1417, San Diego.

Simkin, T., Siebert, L., McClelland, L., Bridge, D., Ne- 
whall, C. \& J.H. Latter, 1981: Volcanoes of the World.- Smithsonian Institution, pp. 232, Washington, D.C.

Toulkeridis, T., 2013: Volcanic Galápagos Volcánico.Published by the author, pp. 338, Quito, Ecuador.

Vigouroux, N., Williams-Jones, G., Geist, D., Chadwick, W., Ruiz, A. \& D. Johnson, 2008: 4D gravity changes associated with the 2005 eruption of Sierra Negra volcano, Galápagos.- Geophysics, 73, 6, WA29WA35. https://doi.org/10.1190/1.2987399

Werner, R., Hoernle, K., Barckhausen, U. \& F. Hauff, 2003: Geodynamic evolution of the Galápagos hot spot system (Central East Pacific) over the past
20 m.y.: Constraints from morphology, geochemistry and magnetic anomalies.- Geochemistry, Geophysics, Geosystems, 4, 12, 1108. https://doi. org/10.1029/2003GC000576

White, W.M., McBirney, A.R. \& R.A. Duncan, 1993: Petrology and geochemistry of the Galápagos Islands: Portrait of a pathological mantle plume.- Journal of Geophysical Research, 98, B11, 19533-19563. https://doi.org/10.1029/93JB02018

Wolfe, E.W. (ed.), 1988: The Pu'u 'Ō'ō-Eruption of Kilauea Volcano, Hawai'i: Episodes 1 through 20, January 3, 1983, through June 8, 1984.- US Geological Survey Professional Paper, 1463, pp. 251. 